\title{
C-Terminal Interaction Is Essential for Surface Trafficking But Not for Heteromeric Assembly of GABA Receptors $_{B}$
}

\author{
Adriana Pagano, ${ }^{1,2}$ Giorgio Rovelli, ${ }^{1}$ Johannes Mosbacher, ${ }^{1}$ Tania Lohmann, ${ }^{1,4}$ Beatrice Duthey, ${ }^{3}$ \\ Daniela Stauffer, ${ }^{1}$ Dorothee Ristig, ${ }^{1}$ Valerie Schuler, ${ }^{1}$ Ingeborg Meigel, ${ }^{1}$ Christina Lampert, ${ }^{1}$ Thomas Stein, ${ }^{1}$ \\ Laurent Prézeau, ${ }^{3}$ Jaroslav Blahos, ${ }^{3}$ Jean-Philippe Pin, ${ }^{3}$ Wolfgang Froestl, ${ }^{1}$ Rainer Kuhn, ${ }^{1}$ Jakob Heid, ${ }^{1}$ \\ Klemens Kaupmann, ${ }^{1}$ and Bernhard Bettler ${ }^{1}$ \\ ${ }^{1}$ Novartis Pharma AG, Therapeutic Area Nervous System, CH-4002 Basle, Switzerland, 2Dipartimento di Scienze \\ Chimiche, Università di Catania, 95125 Catania, Italy, ${ }^{3}$ Mécanismes Moléculaires des Communications Cellulaires UPR \\ 9023, Centre National de la Recherche Scientifique CCIPE, 34094 Montpellier Cedex 05, France, and 4 Departamento de \\ Fisiologia e Biofísica, Instituto de Ciências Biomédicas, Universidade de São Paulo-ICB/USP, 05508-900, São Paulo, Brazil
}

Assembly of fully functional $\mathrm{GABA}_{\mathrm{B}}$ receptors requires heteromerization of the $\mathrm{GABA}_{\mathrm{B}(1)}$ and $\mathrm{GABA}_{\mathrm{B}(2)}$ subunits. It is thought that $\mathrm{GABA}_{\mathrm{B}(1)}$ and $\mathrm{GABA}_{\mathrm{B}(2)}$ undergo coiled-coil dimerization in their cytoplasmic $C$ termini and that assembly is necessary to

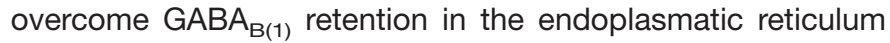
(ER). We investigated the mechanism underlying $\mathrm{GABA}_{\mathrm{B}(1)}$ trafficking to the cell surface. We identified a signal, RSRR, proximal to the coiled-coil domain of $\mathrm{GABA}_{\mathrm{B}(1)}$ that when deleted or mutagenized allows for surface delivery in the absence of $\mathrm{GABA}_{\mathrm{B}(2)}$. A similar motif, RXR, was recently shown to function as an ER retention/retrieval (ERR/R) signal in $\mathrm{K}_{\mathrm{ATP}}$ channels, demonstrating that G-protein-coupled receptors (GPCRs) and ion channels use common mechanisms to control surface trafficking. A C-terminal fragment of $\mathrm{GABA}_{\mathrm{B}(2)}$ is able to mask the RSRR signal and to direct the $\mathrm{GABA}_{\mathrm{B}(1)}$ monomer to the cell

$\mathrm{GABA}_{\mathrm{B}}$ receptors are G-protein-coupled receptors (GPCRs) that, by activating second messenger cascades and modulating ion channel activity, control neurotransmitter release and postsynaptic silencing of excitatory neurotransmission (Marshall et al., 1999). They have been implicated in hippocampal long-term potentiation, short-wave sleep, muscle relaxation, and antinociception (Kim et al., 1997; Bettler et al., 1998). GABA B $_{\text {receptors }}$ belong to the family 3 GPCRs and as such share homology with metabotropic glutamate (mGlu), $\mathrm{Ca}^{2+}$-sensing, pheromone, and taste receptors. Three prominent $\mathrm{GABA}_{\mathrm{B}}$ proteins, $\mathrm{GABA}_{\mathrm{B}(1 \mathrm{a})}$, $\mathrm{GABA}_{\mathrm{B}(1 \mathrm{~b})}$, and $\mathrm{GABA}_{\mathrm{B}(2)}$ have been identified. $\mathrm{GABA}_{\mathrm{B}(1 \mathrm{a})}$ and $\mathrm{GABA}_{\mathrm{B}(1 \mathrm{~b})}$ derive from the same gene by $\mathrm{N}$-terminal alternative splicing. $\mathrm{GABA}_{\mathrm{B}}$ receptors are expressed on the cell surface as a heteromeric complex of $\mathrm{GABA}_{\mathrm{B}(1 \mathrm{a}, 2)}$ or $\mathrm{GABA}_{\mathrm{B}(1 \mathrm{~b}, 2)}$. Available ligands, such as the photoaffinity antagonist [ $\left.{ }^{125} \mathrm{I}\right] \mathrm{CGP} 71872$, bind to the $\mathrm{N}$-terminal extracellular region that is conserved

Received July 26, 2000; revised Dec. 7, 2000; accepted Dec. 11, 2000.

T.L. was supported by the Fundação de Amparo à Pesquisa do Estado de São Paulo (FAPESP). We thank Dr. A Karschin for Kir3.1/2 concatemers, Drs. R. Kammerer and J. Engel for helpful discussion, Drs. J. Perroy, F. Ango, and V. Bandelier for technical assistance and helpful discussion. A.P. thanks Prof. A. Cambria for his continuous support.

A.P. and G.R. contributed equally to this work.

Correspondence should be addressed to Bernhard Bettler, Nervous System Research, Novartis Pharma AG, K-125.6.08, CH-4002 Basle, Switzerland. E-mail: bernhard.bettler@pharma.novartis.com.

Copyright () 2001 Society for Neuroscience 0270-6474/01/211189-14\$15.00/0 surface, where it is functionally inert. This indicates that in the heteromer, $\mathrm{GABA}_{\mathrm{B}(2)}$ participates in coupling to the G-protein. Mutagenesis of the C-terminal coiled-coil domains in $\mathrm{GABA}_{\mathrm{B}(1)}$ and $\mathrm{GABA}_{\mathrm{B}(2)}$ supports the possibility that their interaction is involved in shielding the ERR/R signal. However, assembly of heteromeric $\mathrm{GABA}_{\mathrm{B}}$ receptors is possible in the absence of the $\mathrm{C}$-terminal domains, indicating that coiled-coil interaction is not necessary for function. Rather than guaranteeing heterodimerization, as previously assumed, the coiled-coil structure appears to be important for export of the receptor complex from the secretory apparatus.

Key words: GABA-B receptor; G-protein; metabotropic; heterodimer; endoplasmatic reticulum; coiled-coil $\alpha$-helices; leucine zippers between the $\mathrm{GABA}_{\mathrm{B}(1 \mathrm{a})}$ and $\mathrm{GABA}_{\mathrm{B}(1 \mathrm{~b})}$ subunits (Galvez et al., 1999; Malitschek et al., 1999).

Although GPCRs were believed to be monomeric entities, a growing body of evidence indicates that they can form dimers (Salahpour et al., 2000). The implications of GPCR dimerization have not been firmly established. $\mathrm{GABA}_{\mathrm{B}}$ receptors are the first GPCRs where not only assembly into heteromeric complexes was demonstrated, but where dimerization also had clear functional consequences (Marshall et al., 1999). Unlike other dimeric GPCRs, where the individual subunits can form receptors in their own right, $\mathrm{GABA}_{\mathrm{B}(1)}$ and $\mathrm{GABA}_{\mathrm{B}(2)}$ are functionally impaired when expressed alone in heterologous cells. Experiments with transfected sympathetic neurons further support the possibility that heteromeric assemblies of $\mathrm{GABA}_{\mathrm{B}(1,2)}$ are essential to mediate functional responses (Filippov et al., 2000). Significantly the $\mathrm{GABA}_{\mathrm{B}(1)}$ and $\mathrm{GABA}_{\mathrm{B}(2)}$ subunits colocalize at extrasynaptic sites and can be copurified from neuronal membranes (Kaupmann et al., 1998a; Benke et al., 1999). Each GABA $_{\text {B }}$ receptor subunit contains a 30 amino acid leucine zipper motif within its intracellular C-terminal domain (White et al., 1998). Leucine zipper peptides of $\mathrm{GABA}_{\mathrm{B}(1)}(\mathrm{LZ1})$ and $\mathrm{GABA}_{\mathrm{B}(2)}(\mathrm{LZ2})$ form a parallel heterodimeric coiled coil but do not undergo significant homodimerization (Kammerer et al., 1999). $\mathrm{GABA}_{\mathrm{B}(1)}$ is retained in the ER when expressed by itself (Couve et al., 1998). The $\mathrm{GABA}_{\mathrm{B}(2)}$ subunit facilitates the intracellular trafficking of $\mathrm{GABA}_{\mathrm{B}(1)}$ from the ER toward the plasma membrane and pro- 
motes the high-affinity agonist conformation of the receptor (Marshall et al., 1999). Despite the identification of heterodimerization as a requirement for function, the mechanism whereby $\mathrm{GABA}_{\mathrm{B}(2)}$ induces an increase in cell surface expression of $\mathrm{GABA}_{\mathrm{B}(1)}$ remained enigmatic.

Here we used mutagenesis, functional expression, surface photoaffinity labeling, and immunocytochemistry to explore the molecular interactions that underlie intracellular retention and heteromer formation of $\mathrm{GABA}_{\mathrm{B}}$ receptors. We demonstrate that $\mathrm{GABA}_{\mathrm{B}(1)}$ carries an $\mathrm{ERR} / \mathrm{R}$ signal located four residues $\mathrm{C}$-terminal of LZ1. This signal restricts plasma membrane incorporation of the $\mathrm{GABA}_{\mathrm{B}(1)}$ subunit in human embryonic kidney 293 (HEK293) cells and neurons. Exposure of the ERR/R signal is masked by $\mathrm{C}$-terminal interactions between $\mathrm{GABA}_{\mathrm{B}(1)}$ and $\mathrm{GABA}_{\mathrm{B}(2)}$, whereas other family 3 GPCRs are ineffective in shielding. In contrast to the prevailing model, it appears that C-terminal interaction between $\mathrm{GABA}_{\mathrm{B}(1)}$ and $\mathrm{GABA}_{\mathrm{B}(2)}$ is not essential for dimerizing the receptor complex per se but rather controls surface trafficking.

\section{MATERIALS AND METHODS}

Generation of mutant expression plasmids. All constructs were subcloned into the cytomegalovirus-based eukaryotic expression vector pCI (Promega, Madison, WI). To allow detection of transiently expressed receptors, the N-terminal 16 residues of rat $\mathrm{GABA}_{\mathrm{B}(1 \mathrm{a})}$ (Kaupmann et al., 1997) were replaced by 36 residues encoding the mGlu5 signal peptide, $M^{1}$ V LLLILSVLLLKEDVRGSAQS ${ }^{22}$, followed by the c-myc epitope, $\mathrm{TRE}^{25} \mathrm{QKLISEEDL}{ }^{34} \mathrm{TR}$. The GABA ${ }_{\mathrm{B}(1)}$ signal peptide was replaced by the mGlu5 signal peptide because the latter is known to accurately release the N-terminal hemagglutinin (HA) epitope tag (Ango et al., 1999). Likewise the $\mathrm{N}$-terminal 41 residues of rat $\mathrm{GABA}_{\mathrm{B}(2)}$ (Kaupmann et al., 1998a) were replaced by the mGlu5 signal peptide followed by the HA epitope, TRY ${ }^{25}$ PYDVPDYA ${ }^{33}$ TR. The presence of the c-myc and HA epitope was found to affect neither the pharmacology nor the expression level of recombinant receptors. A cassette strategy was used to engineer all mutations and truncations. Artificial XhoI and EcoRV sites were introduced by silent site-directed mutagenesis of $\mathrm{G}^{2691} \mathrm{C}$ and $\mathrm{A}^{2694} \mathrm{G}$ in $\mathrm{GABA}_{\mathrm{B}(1 \mathrm{a})}$ and $\mathrm{C}^{2508} \mathrm{~T}$ in $\mathrm{GABA}_{\mathrm{B}(2)}$, respectively. Chimera R1CR2 was made by overlap extension PCR. $\mathrm{GABA}_{\mathrm{B}(1 \mathrm{a})}$ was amplified using a forward primer (bp 1941-1958) and a chimeric reverse primer containing $\mathrm{GABA}_{\mathrm{B}(1 \mathrm{a})}$ (bp 2539-2559) and $\mathrm{GABA}_{\mathrm{B}(2)}$ (bp 2224-2244) sequences. The $\mathrm{GABA}_{\mathrm{B}(2)} \mathrm{C}$-terminal tail was amplified by using chimeric primer complementary to the one described above and a reverse primer (bp 2803-2823) with an in-frame 4xHis tag and a stop codon followed by an XhoI site. The two PCR products were joined by PCR and subcloned into the ClaI (bp 2245)/XhoI sites of $\mathrm{GABA}_{\mathrm{B}(1 \mathrm{a})}$. Chimera R2CR1 was made as described above, with primers containing both $\mathrm{GABA}_{\mathrm{B}(2)}$ (bp 2194-2223) and $\mathrm{GABA}_{\mathrm{B}(1 \mathrm{a})}$ sequences (bp 2560-2588). The $\mathrm{GABA}_{\mathrm{B}(1 \mathrm{a})} \mathrm{C}$-terminal tail was amplified using reverse primer (bp 2863-2880) with an in-frame 4xHis tag and a stop codon followed by an Not I site. The $4 \mathrm{xHis}$ tags were added to monitor expression of the R2T749 his, R1CR2 his, and R2CR1 his constructs. We alternatively used the HA tag at the $\mathrm{N}$ terminus of R2T749. R2T749_his and R2T749_ha show no overt differences in expression levels, as well as in pharmacological and functional properties. The final PCR product was subcloned into the RsrII (bp1661)/NotI sites of $\mathrm{GABA}_{\mathrm{B}(2)}$. The $\mathrm{GABA}_{\mathrm{B}(1 \mathrm{a})} \mathrm{C}$-terminal truncations R1I860, R1T872, and R1K886 were constructed by ligating complementary oligonucleotides with appropriate overhangs into $B c l \mathrm{I}^{2576} / E c o$ RI (3' cloning site). Using XhoI/EcoRI sites we made R1L915, R1L921, and R1P928. By ligating complementary oligonucleotides into EheI ${ }^{2771} / E c o R I$ sites we made R1G940 and R1G952. $\mathrm{GABA}_{\mathrm{B}(1 \mathrm{a})}$ alanine scanning from residue $\mathrm{R}^{922}$ to $\mathrm{P}^{928}$ and mutants with $\mathrm{S}^{923} \rightarrow \mathrm{D}, \mathrm{RR}^{922 / 924} \rightarrow \mathrm{AA}$, and $\mathrm{RRR}^{922 / 924 / 925} \rightarrow \mathrm{AAA}$ changes were constructed by site-directed mutagenesis and subcloned into $X h o \mathrm{I} / E c o$ RI. The GABA $\mathrm{B}(1 \mathrm{a})$ LZ1 (bp 2650-2751) (Kammerer et

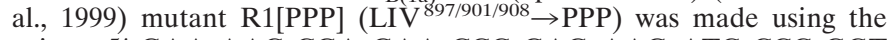
primer 5'-GAA AAC CGA GAA CCC GAG AAG ATC CCC GCT GAG AAA GAG GAG CGC CCC TCT GAA CTG CG-3'. The LZ1 deletion mutant $\mathrm{R} 1 \Delta \mathrm{LZ}$ was generated from wild-type (WT) $\mathrm{GABA}_{\mathrm{B}(1 \mathrm{a})}$ using complementary 44mer oligonucleotides flanking LZ1 (bp 26262649 and 2752-2772). We used overlap extension PCR to construct
R1LZ2 by amplifying LZ2 (bp 2354-2454) (Kammerer et al., 1999) with chimeric primers complementary to WT GABA $\mathrm{B}_{(1 \mathrm{a})}$ and $\mathrm{GABA}_{\mathrm{B}(2)}$ (bp 2353-2373, 2431-2454). The amplified LZ2 domain was then inserted into $\mathrm{R} 1 \Delta \mathrm{LZ}$. The $\mathrm{GABA}_{\mathrm{B}(2)} \mathrm{C}$-terminal truncation $\mathrm{R} 2 \mathrm{~T} 749$ was made by ligating complementary oligonucleotides with appropriate overhangs in MluI (bp 2136)/XbaI (3' cloning site); truncations R2L791, R2E811, and R2P820 were constructed by taking advantage of PshAI (bp 2368)/XbaI sites. CR2 $\left(\mathrm{R}^{714}-\mathrm{L}^{941}\right)$ and CR2P820 $\left(\mathrm{R}^{714}-\mathrm{P}^{820}\right)$ were made by removing the N-terminal and transmembrane domain (TMD)1-6 domains from the WT and $\mathrm{R} 2 \mathrm{P} 820 \mathrm{GABA}_{\mathrm{B}(2)}$ constructs by MluI digestion and religation, thereby preserving the previously inserted HA tag. R2[PPP] with mutation of $\mathrm{LIL}^{798 / 802 / 805} \rightarrow$ PPP was made using primer $5^{\prime}$-GAA AAC CAC CGC CCG CGG ATG AAG CCC ACA GAG CCG GAC AAA GAC TTG-3'. The LZ2 deletion in R2 $\Delta \mathrm{LZ}$ was made using complementary 48mer oligonucleotides flanking LZ2 (bp 2311-2334 and 2437-2460). We made chimera R2LZ1 by inserting LZ1 into WT GABA $\mathrm{B}_{(2)}$. PCR using a forward primer duplicating sequences complementary to $\mathrm{GABA}_{\mathrm{B}(2)}$ (bp 2311-2334) and $\mathrm{GABA}_{\mathrm{B}(1 \mathrm{a})}$ (bp 2650-2672) amplified $\mathrm{LZ1}$; reverse primer corresponded to chimeric $\mathrm{GABA}_{\mathrm{B}(1 \mathrm{a})}$ (bp 27292751) and $\mathrm{GABA}_{\mathrm{B}(2)}$ sequences (bp 2437-2460). All constructs were verified by sequencing.

Cell culture and radioligand binding assays. Mammalian cells were purchased from the American Type Culture Collection (Rockville, MD) and cultured in Earle's MEM (Life Technologies, Basel, Switzerland) supplemented with $10 \%$ fetal calf serum and $2 \mathrm{~mm}$ L-glutamine. Cells were harvested for membrane preparation $2 \mathrm{~d}$ after transfection. Preparation of cell lysates and [ ${ }^{125}$ I]CGP64213 binding assays was performed as described (Kaupmann et al., 1997). [ [ $\left.{ }^{125} \mathrm{I}\right] \mathrm{CGP} 64213$ and $\left[{ }^{125}\right.$ I]CGP71872 were radiolabeled (ANAWA, Wangen, Switzerland) to a specific activity of $2000 \mathrm{Ci} / \mathrm{mmol}$. All ligands were synthesized in house.

Immunoblot. Cellular membranes were solubilized in Laemmli sample buffer (125 mм Tris, pH 6.8, 1\% SDS, 25 mm DTT, 5\% glycerol/ bromphenol blue). Proteins $(10-20 \mu \mathrm{g}$ per lane) were separated by SDS-PAGE using 4-15\% gradient gels and transferred onto Immobilon-P polyvinylidene difluoride membranes (Millipore AG, Volketswil, Switzerland) by standard wet electrophoretic transfer. Blocking was overnight in NET-G buffer ( $150 \mathrm{~mm} \mathrm{NaCl}, 50 \mathrm{~mm}$ EDTA, 500 $\mathrm{mm}$ Tris $\mathrm{HCl}, \mathrm{pH} 7.4,0.5 \% \mathrm{v} / \mathrm{v}$ Triton $\mathrm{X}-100,2.5 \% \mathrm{w} / \mathrm{v}$ gelatin) at $4^{\circ} \mathrm{C}$. Incubation with primary and secondary antibodies was for $45 \mathrm{~min}$ at room temperature. Polyclonal rabbit antisera Ab174.1, Ab176a, and C22 were as described (Malitschek et al., 1998; Kaupmann et al., 1998a,b). Polyclonal antisera N22 was derived against the $\mathrm{GABA}_{\mathrm{B}(2)} \mathrm{N}$-terminal peptide $\mathrm{A}^{164}-\mathrm{L}^{215}$ and produced as described (Malitschek et al., 1998). Antibodies were diluted in NET-G buffer as follows: Ab174.1 (1:2000), Ab176a (1:2000), N22 (1:2000), C22 (1:3000), and goat anti-rabbit IgG H+L POD (1:3000; Bio-Rad, Glattbrugg, Switzerland). Detection was with enhanced chemiluminescent Western Blot reagents (Amersham, Duebendorf, Switzerland) and exposure to Biomax maximum resolution x-ray films (Kodak, Cambridge, UK).

Surface labeling experiments. Given that $\left[{ }^{125} \mathrm{I}\right] \mathrm{CGP} 71872$ cannot permeate the plasma membrane, photoaffinity labeling of intact cells reveals receptor/ligand interactions that occur at the extracellular binding site (Malitschek et al., 1999). HEK293 cells were transferred to six-well plates $6 \mathrm{hr}$ after transfection. After an additional $36 \mathrm{hr}$ incubation, cells were washed twice with cold HEPES buffer, $\mathrm{pH}$ 7.6 (Life Technologies). Half of the cells were used for photoaffinity labeling of surface receptors (S), the other half for labeling of receptors in the cell homogenate $(\mathrm{H})$. For labeling of surface receptors, living cells were incubated in the dark for $1 \mathrm{hr}$ at room temperature with $0.8 \mathrm{nM}\left[{ }^{125} \mathrm{I}\right] \mathrm{CGP} 71872$. Cells were washed with cold HEPES buffer to remove unbound [ ${ }^{125}$ I]CGP71872 before UV cross-linking (Kaupmann et al., 1997). Photoaffinity-labeled cells were collected, and the radioactivity was determined in a gamma counter (Packard, Zurich, Switzerland). Photoaffinity labeling of receptors in the membrane fraction was as described (Kaupmann et al., 1997). For SDS-PAGE, the pellets of cells and cell lysates were resuspended in HEPES buffer containing $0.1 \%$ SDS. An aliquot was taken for protein determination (Micro BCA Protein Assay Reagent Kit, Pierce, Rockford, IL). Twenty micrograms of total protein of cell and membrane fraction were loaded onto a $4-15 \%$ gradient gel. Photoaffinity-labeled proteins were detected using autoradiography. The radioactivity incorporated into the surface $(\mathrm{S})$ and homogenate $(\mathrm{H})$ fraction was normalized to the respective amount of protein in each fraction before the percentage S/H ratio was calculated. Presumably because of the differences in the radiolabeling procedure for surface and homogenate recep- 
tors, the percentage $\mathrm{S} / \mathrm{H}$ sometimes exceeds the theoretical value of $100 \%$.

Immunofluorescence studies. HEK293 cells were grown on eight-well glass slides coated with poly-D-lysine (Becton Dickinson, Basle, Switzerland $)$ and transfected $\left(0.05 \mu \mathrm{g}\right.$ of $\mathrm{GABA}_{\mathrm{B}(1 \mathrm{a})} / 0.2 \mu \mathrm{g}$ of $\mathrm{GABA}_{\mathrm{B}(2)}$ DNA in $5 \mu \mathrm{l}$ of $\mathrm{H}_{2} \mathrm{O}$ ) with FuGene6 (Roche Molecular Biochemicals, Rotkreuz, Switzerland). In control experiments the empty pCI vector substituted for $\mathrm{GABA}_{\mathrm{B}}$ plasmids. Dissociated cerebellar granule cells were isolated from 7-d-old mice and plated on poly-L-ornithine-coated $35 \mathrm{~mm}$ glass coverslips (Van-Vliet et al., 1989); after $7 \mathrm{~d}$ in culture, cells were transfected (Ango et al., 1999) with c-myc and HA-tagged $\mathrm{GABA}_{\mathrm{B}(1 \mathrm{a})}$ and $\mathrm{GABA}_{\mathrm{B}(2)}$ constructs, respectively. Cells were fixed $48 \mathrm{hr}$ after transfection with $4 \%$ paraformaldehyde in PBS for 20 min and blocked with $1 \%$ BSA and $2 \%$ heat-inactivated goat serum in PBS for $1 \mathrm{hr}$. Cell surface receptor expression was assayed by labeling cells with either anti-c-myc (clone 9E10, Roche Molecular Biochemicals; 1:200) or anti-HA (clone 12CA5, Roche Molecular Biochemicals; 1:80) monoclonal antibodies for $2 \mathrm{hr}$. After extensive washing, cells were incubated for $1 \mathrm{hr}$ with secondary Cy3-conjugated affinity-purified goat anti-mouse IgG (1:400, Jackson ImmunoResearch Laboratories, West Grove, PA). Intracellular receptor expression was assayed with permeabilized cells $(0.4 \%$ saponin added to the blocking/washing buffers and to the primary and secondary antibody solutions). Immunofluorescence microscopy was with a Zeiss Axioplan microscope using a $20 \times$ Plan-Neofluar objective. Images were collected with a Hamamatsu 3 CCD digital camera.

Measurement of $\left.\mathrm{\Delta} / \mathrm{Ca}^{2+}\right]_{I}$ by fluorometry. For measurement of $\Delta\left[\mathrm{Ca}^{2+}\right]_{\mathrm{i}}$ all transfections included $\mathrm{G} \alpha_{\mathrm{qo} 5}$ to couple $\mathrm{GABA}_{\mathrm{B}}$ receptors to PLC (Franek et al., 1999). HEK293 cells $\left(1.5 \times 10^{6}\right)$ were electroporated $(250 \mathrm{~V}, 300 \mu \mathrm{F}$; BioRad Gene Pulser) with $5 \mu \mathrm{g}$ of cDNA constructs in a total volume of $150 \mu \mathrm{l}$ buffer $\left(50 \mathrm{~mm} \mathrm{~K}_{2} \mathrm{HPO}_{4}, 20 \mathrm{~mm} \mathrm{CH}_{3} \mathrm{COOK}, 20\right.$ $\mathrm{mm} \mathrm{KOH,} \mathrm{pH}$ 7.4). Transfected cells were resuspended in culture medium and split into three wells of 12 -well plates that were coated with 100 $\mathrm{mg} / \mathrm{ml}$ poly-D-lysine. Twenty-four hours after transfection, the cells were incubated at room temperature for $1 \mathrm{hr}$ in a HEPES buffer, $\mathrm{pH}$ 7.6 (Life Technologies) containing $10 \mu \mathrm{g} / \mathrm{ml}$ of the calcium indicator fura-2 AM, 0.5\% Pluronic F-127 (Molecular Probes, Eugene, OR), and 1\% (v/v) dimethyl sulfoxide. Glass coverslips carrying dye-loaded cells were mounted into a perfused cuvette $(2 \mathrm{ml} / \mathrm{min})$ in a fluorescence spectrophotometer (F-4500, Hitachi). Changes in $\left[\mathrm{Ca}^{2+}\right]_{\mathrm{i}}$ were monitored by measuring the ratio of fura- 2 fluorescence $(510 \mathrm{~nm})$ excited at 340 and $380 \mathrm{~nm}$, switched at $1.6 \mathrm{~Hz}$. The viability of transfected cells was tested by application of $10 \mu \mathrm{M}$ ATP. Control experiments showed no changes in $\left[\mathrm{Ca}^{2+}\right]_{\mathrm{i}}$ levels after application of $1 \mathrm{mM}$ GABA in HEK293 cells transfected with pcDNA1 vector and in HEK293 cells expressing $\mathrm{GABA}_{\mathrm{B}(1)}+\mathrm{G} \alpha_{\mathrm{qo} 5}, \mathrm{GABA}_{\mathrm{B}(2)}+\mathrm{G} \alpha_{\mathrm{qo} 5}$, or $\mathrm{G} \alpha_{\mathrm{qo} 5}$. No quantitative comparison between experiments was made, because the signal amplitude depends on the transfection efficiency.

Fluorometric image plate reader. Transfected HEK293 cells were plated into poly-D-lysine coated 96-well plates (Becton Dickinson). After transfection (48-72 hr), cells were loaded for 45 min with $2 \mu \mathrm{M}$ fluo-4 AM (Molecular Probes) in HBS (Life Technologies) containing $50 \mu \mathrm{M}$ probenecid (Sigma, Buchs, Switzerland). Plates were washed and transferred to a FLIPR (Molecular Devices, Crawley, UK). Concentration-response curves were recorded with three to eight wells per concentration as a change of fluorescence over baseline $(\Delta F / F)$. Data were fitted using Igor Pro (Wavemetrics) with a logistic equation using weighted nonlinear regression. Curves and data points were normalized to their asymptotic maximal values or for negative subunit combinations to the respective values of the positive controls measured on the same plate.

Electrophysiology. Concatemers of Kir3.1/3.2 subunits (Kaupmann et al., 1998b) were cotransfected with $\mathrm{GABA}_{\mathrm{B}} \mathrm{R}$ cDNA combinations into HEK293 cells. Whole-cell patch-clamp recordings were performed at room temperature $48-72 \mathrm{hr}$ after transfection in a bath solution consisting of (in mM): $135 \mathrm{NaCl}, 5.4 \mathrm{KCl}, 1.8 \mathrm{CaCl}_{2}, 1 \mathrm{MgCl}_{2}, 10$ glucose, 5 HEPES, pH 7.4. Patch pipettes were pulled from borosilicate glass capillaries, heat-polished to give a tip resistance of 3-5 $\mathrm{M} \Omega$, and filled with $140 \mathrm{~mm} \mathrm{KCl}, 2 \mathrm{~mm} \mathrm{MgCl}_{2}$, 1 mM EGTA, 1 mM Na $2 \mathrm{ATP}, 100 \mu \mathrm{M}$ cAMP, $100 \mu \mathrm{M}$ GTP, and $5 \mathrm{mM}$ HEPES, pH 7.3. Currents were elicited at a holding potential of $-90 \mathrm{mV}$ by application of GABA in a high potassium extracellular buffer $(25 \mathrm{~mm} \mathrm{KCl}, 115.6 \mathrm{~mm} \mathrm{NaCl})$. Data were recorded with an Axopatch 200B using pClamp6.

\section{RESULTS}

Previous studies indicated that $\mathrm{GABA}_{\mathrm{B}}$ receptor assembly and trafficking are intricately linked processes and that functional activity of the $\mathrm{GABA}_{\mathrm{B}(1,2)}$ heteromer correlated with $\mathrm{GABA}_{\mathrm{B}(1)}$ cell surface expression (Couve et al., 1998; White et al., 1998). Functional expression in heterologous systems therefore provides a fast and sensitive means of identifying structural elements that are necessary for receptor maturation. In this study we constructed chimeric, truncated, and point mutated $\mathrm{GABA}_{\mathrm{B}(1)}$ and $\mathrm{GABA}_{\mathrm{B}(2)}$ mutants and coexpressed them in HEK293 cells and cultured neurons. Immunoblot analysis was used to verify that all receptor mutants were expressed. For functional analysis we measured $\mathrm{G} \alpha_{\mathrm{qo} 5}$ signaling to phospholipase C (PLC), as manifested by GABA-elicited increases in cytosolic calcium $\left(\left[\mathrm{Ca}^{2+}\right]_{\mathrm{i}}\right)$ (Franek et al., 1999) and G $\beta \gamma$ stimulation of Kir3.1 + 3.2 type $\mathrm{K}^{+}$channels $\left(\mathrm{I}_{\mathrm{Kir} 3.1}+{ }_{3.2}\right)$ (Kaupmann et al., 1998b). Surface expression was studied using immunocytochemistry and quantified using photoaffinity labeling with the membrane-impermeable $\mathrm{GABA}_{\mathrm{B}(1)}$-specific ligand $\left[{ }^{125} \mathrm{I}\right] \mathrm{CGP} 71872$ (Kaupmann et al., 1997). The surface expression and functional data are summarized in the Table.

\section{Reciprocal exchange of the $\mathbf{C}$ terminus allows the assembly of functional heterodimers}

A likely location for a putative ERR/R signal in $\mathrm{GABA}_{\mathrm{B}(1)}$ is the cytoplasmic $\mathrm{C}$-terminal domain. We therefore first investigated whether differences in the carboxyl-tails between $\mathrm{GABA}_{\mathrm{B}(1)}$ and $\mathrm{GABA}_{\mathrm{B}(2)}$ affect $\mathrm{GABA}_{\mathrm{B}(1)}$ cell surface targeting and, as a consequence of this, prevent function. We generated two chimeric subunits, R1CR2 and R2CR1, in which the entire C-terminal domains of $\mathrm{GABA}_{\mathrm{B}(1)}(\mathrm{CR} 1)$ and $\mathrm{GABA}_{\mathrm{B}(2)}(\mathrm{CR} 2)$ were interchanged (Fig. $1 A, B, D, E$ ). The results show that exchange of the C-terminal domains does not allow for homomeric (R1CR2, R2CR1; data not shown) or homodimeric receptor (R1+R1CR2, $\mathrm{R} 2 \mathrm{CR} 1+\mathrm{R} 2$ ) (Fig. $1 \mathrm{~B}$ ) function regardless of the $\mathrm{C}$-terminal domains. It appears that transfer of the $\mathrm{C}$ termini leads to functional expression whenever the $\mathrm{C}$ termini are complementary $(\mathrm{R} 1+\mathrm{R} 2, \mathrm{R} 1 \mathrm{CR} 2+\mathrm{R} 2 \mathrm{CR} 1)$ or from $\mathrm{GABA}_{\mathrm{B}(2)}$ alone (R1CR2+R2) (Fig. 1B). The functional R1CR2+R2 receptor heterodimerizes through domains other than the leuzine zippers, because LZ2 does not dimerize with itself (Kammerer et al., 1999). The above results are consistent with the presence of an $\mathrm{ERR} / \mathrm{R}$ signal in the $\mathrm{C}$ terminus of $\mathrm{GABA}_{\mathrm{B}(1)}$ that impedes surface trafficking and function when not neutralized by C-terminal $\mathrm{GABA}_{\mathrm{B}(2)}$ sequences, as is the case with $\mathrm{R} 2 \mathrm{CR} 1+\mathrm{R} 1$ (Fig. $1 B$ ). Surface expression of the $\mathrm{C}$-terminal exchange mutants was tested using photoaffinity labeling. The results confirm that $\mathrm{GABA}_{\mathrm{B}(1)}$ is retained intracellularly when containing its own $\mathrm{C}$ terminus (R1) (Fig. $1 E$ ) or expressed with R2CR1, but not when containing the $\mathrm{GABA}_{\mathrm{B}(2)} \mathrm{C}$ terminus (R1CR2) (Fig. 1E).

\section{Removal of the $\mathrm{GABA}_{\mathrm{B}(1)} \mathrm{C}$ terminus allows the assembly of functional heterodimers}

The above results raised the possibility that receptor dimerization and functional cell surface expression can occur in the absence of $\mathrm{C}$-terminal domains. We therefore removed the C-terminal domains of $\mathrm{GABA}_{\mathrm{B}(1)}(\mathrm{R} 1 \mathrm{~K} 886)$ and $\mathrm{GABA}_{\mathrm{B}(2)}$ (R2T749) (Fig. $1 A, C, D, E)$. When expressed individually the $\mathrm{C}$-terminally truncated subunits do not yield functional responses (data not shown). However, R1K886 is functional in combination with $\mathrm{GABA}_{\mathrm{B}(2)}(\mathrm{R} 1 \mathrm{~K} 886+\mathrm{R} 2)$ and truncated $\mathrm{GABA}_{\mathrm{B}(2)}(\mathrm{R} 1 \mathrm{~K} 886+$ R2T749) (Fig. 1C). The R1K886+R2T749 receptor emphasizes that heteromerization and G-protein signaling do not depend on C-terminal sequences, including the leucine zipper domains. This indicates that TMD and/or N-terminal domains are sufficient to 
Table 1. Surface expression and functional coupling of $\mathrm{GABA}_{\mathrm{B}}$ receptor mutants

Wild type

R1 C-terminal deletions

Alanine scanning

R2 C-terminal deletions

Leucine zipper deletions and exchanges

Proline mutations within leucine zippers

$\mathrm{R} 1+\mathrm{R} 2$

R1

R1_myc

R1CR2_his

$\mathrm{R} 1+\mathrm{R} 1 \mathrm{CR} 2$ his

$\mathrm{R} 1+\mathrm{R} 2 \mathrm{CR} 1$ _his

R1I860_myc

R1T872_myc

R1K886

R1K886_myc

R1L915_myc

R1L921_myc

R1P928_myc

R1G940_myc

R1G952_myc

R1[스RRHPP]_myc

R1[RARHPP]_myc

R1[RSARHPP]_myc

R1[RSR $\underline{A} H P P]$ myc

R1[RSRR $\underline{\text { APP]_myc }}$

R1[RSRRHA्P]_myc

R1[RSRRHPA]_myc

R1[RDRRHPP]_myc

R1[소슨 RPP]_myc

R1[소슥P]_myc

R1+R2T749_his

R1+R2L791_ha

R1+R2E811_ha

R1+R2P820_ha

$\mathrm{R} 1 \Delta \mathrm{LZ} 1$

$\mathrm{R} 1 \Delta \mathrm{LZ} 1+\mathrm{R} 2$

$\mathrm{R} 1 \Delta \mathrm{LZ} 1+\mathrm{R} 2 \mathrm{~T} 749$ his

$\mathrm{R} 1 \Delta \mathrm{LZ} 1+\mathrm{R} 2[\mathrm{PPP}]$

R1LZ2

$\mathrm{R} 1 \mathrm{LZ2}+\mathrm{R} 2$

R1LZ2+R2T749_his

$\mathrm{R} 2 \Delta \mathrm{LZ} 2+\mathrm{R} 1$

$\mathrm{R} 2 \Delta \mathrm{LZ} 2+\mathrm{R} 1 \Delta \mathrm{LZ} 1$

$\mathrm{R} 2 \mathrm{LZ1+R} 1$

R2LZ1+R1LZ2

$\mathrm{R} 1[\mathrm{PPP}]$

$\mathrm{R} 1[\mathrm{PPP}]+\mathrm{R} 2$

$\mathrm{R} 1+\mathrm{R} 2[\mathrm{PPP}]$

$\mathrm{R} 1[\mathrm{PPP}]+\mathrm{R} 2[\mathrm{PPP}]$

R1I860_myc+R2[PPP]

R1[PPP]+R2T749_his
Surface photoaffinity labeling

91

6

21

146

n.d.

7

141

116

160

129

131

73

5

13

6

$105 / 385^{a}$

$6 / 36^{a}$

$68 / 80^{a}$

$23 / 56^{a}$

$8 / 7^{a}$

$4 / 24^{a}$

$10 / 28^{a}$

$40 / 183^{a}$

$126 / 106^{a}$

$152 / 181^{a}$

23

17

34

254

284

225

150

140

30

177

40

24

103

49

153

7

135

108

70

247

n.d.

\begin{tabular}{|c|c|}
\hline $\begin{array}{l}\text { Surface } \\
\text { immunostaining }\end{array}$ & $\begin{array}{l}\text { G-protein } \\
\text { coupling }\end{array}$ \\
\hline+ & + \\
\hline- & - \\
\hline- & - \\
\hline+ & - \\
\hline+ & - \\
\hline n.d. & - \\
\hline+ & $++^{a} /+^{b}$ \\
\hline+ & $++^{a} /+^{b}$ \\
\hline+ & $+^{a} /+^{b}$ \\
\hline+ & $+^{a} /+^{b}$ \\
\hline+ & $++^{a} /+^{b}$ \\
\hline+ & $+^{a} /+^{b}$ \\
\hline- & $-{ }^{a} /+^{b}$ \\
\hline- & $-{ }^{a} /+^{b}$ \\
\hline- & $-{ }^{a} /+^{b}$ \\
\hline+ & $+^{a} /+^{b}$ \\
\hline- & $-{ }^{a} /+^{b}$ \\
\hline+ & $++^{a} /+^{b}$ \\
\hline+ & $+^{a} /+^{b}$ \\
\hline- & $-{ }^{a} /+^{b}$ \\
\hline- & $-{ }^{a} /+^{b}$ \\
\hline- & $-{ }^{a} /+^{b}$ \\
\hline+ & $++^{a} /+^{b}$ \\
\hline+ & $+^{a} /+^{b}$ \\
\hline+ & $+^{a} /+^{b}$ \\
\hline- & - \\
\hline- & - \\
\hline- & + \\
\hline+ & + \\
\hline+ & - \\
\hline+ & + \\
\hline n.d. & + \\
\hline n.d. & + \\
\hline- & - \\
\hline+ & + \\
\hline+ & + \\
\hline- & - \\
\hline n.d. & + \\
\hline- & + \\
\hline+ & + \\
\hline- & - \\
\hline+ & + \\
\hline n.d. & + \\
\hline+ & + \\
\hline+ & + \\
\hline- & - \\
\hline
\end{tabular}

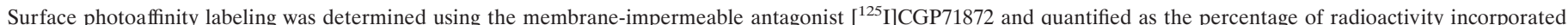

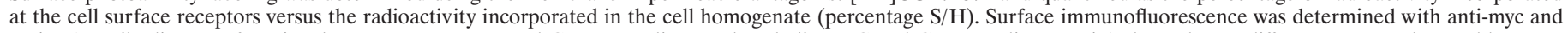

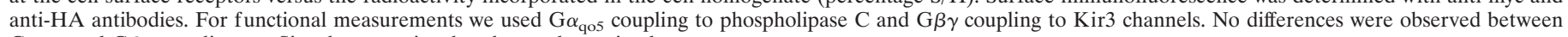
$\mathrm{G} \alpha_{\mathrm{qo} 5}$ and $\mathrm{G} \beta \gamma$ coupling. +, Signal; -, no signal; n.d., not determined.

${ }^{a}$ Experiments with co-expressed R2T749_his.

${ }^{b}$ Experiments with co-expressed WT GABA $\mathrm{B}(2)$.

form an interface that supports assembly of a functional heteromeric receptor. This is in line with homodimerization of mGlu5 and $\mathrm{Ca}^{2+}$-sensing receptors that occurs in the N-terminal extracellular domains (Romano et al., 1996; Ward et al., 1998; Bai et al., 1999; Ray et al., 1999). The R1+R2T749 (Fig. 1C) and
R1K886+R2CR1 (Fig. 1D) subunit combinations are not functional. These results are consistent with the presence of an $\mathrm{ERR} / \mathrm{R}$ signal in the $\mathrm{C}$ terminus of $\mathrm{GABA}_{\mathrm{B}(1)}$ that impedes surface trafficking and function. In agreement with this proposal, the R1CR2+R2T749 combination, where the putative ERR/R 

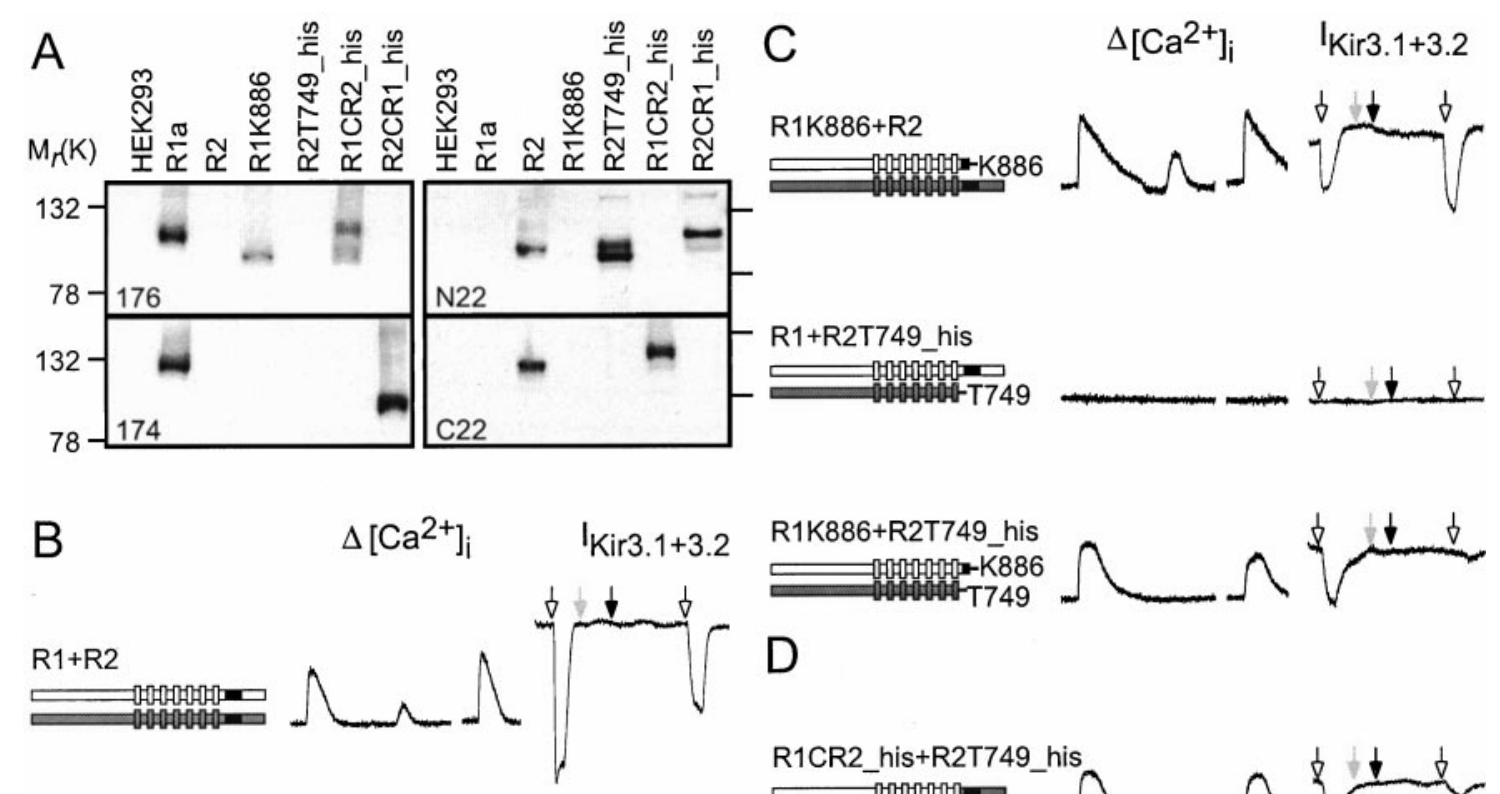

R1+R1CR2_his
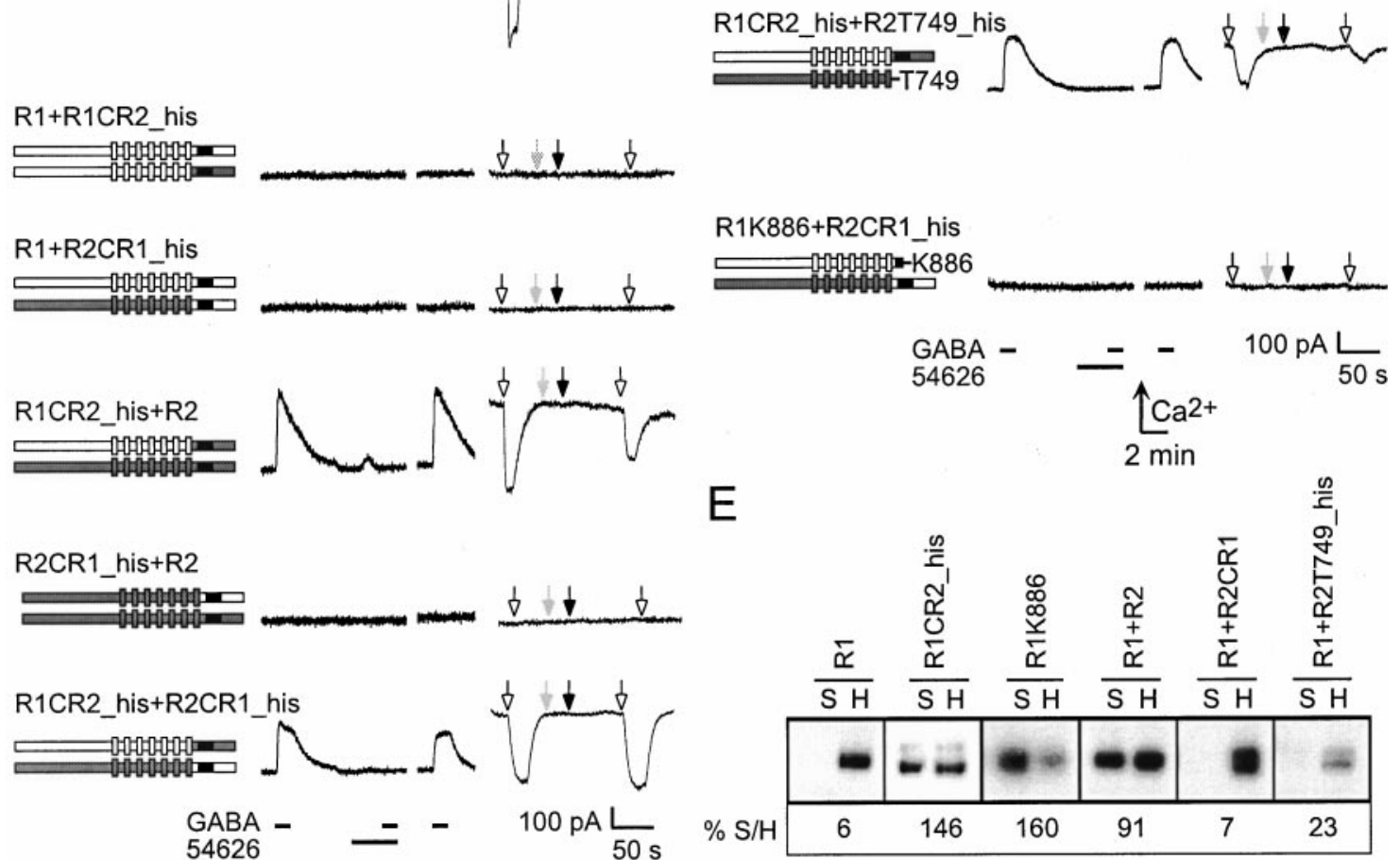

Figure 1. Functional expression and cell surface targeting of C-terminal exchange and deletion mutants in HEK293 cells. $A$, Immunoblot analysis of $\mathrm{WT} \mathrm{GABA}_{\mathrm{B}(1 \mathrm{a})}(R 1 a)$, WT GABA $\mathrm{B}_{(2)}(R 2)$, and mutant proteins. Antibodies directed to N- $(176, N 22)$ and C-terminal $(174, C 22)$ epitopes of GABA $\mathrm{B}(1)$ $(176,174)$ and $\mathrm{GABA}_{\mathrm{B}(2)}(N 22, C 22)$ were used. $B, C, D$, Functional analysis of C-terminal exchange and deletion mutants in fluorometer. Functional coupling to PLC shows representative $\mathrm{Ca}^{2+}$ transients as measured by changes in fura-2 fluorescence intensity ratios $\left(\mathrm{R}_{340 / 380}, \Delta / C a^{2+} J_{i}\right)$. Bars below traces indicate application of drugs. GABA $(100 \mu \mathrm{M})$-evoked changes in $\left[\mathrm{Ca}^{2+}\right]_{\mathrm{i}}$ are reversibly inhibited by coapplication of the GABA $\mathrm{B}_{\mathrm{B}}$ receptor antagonist CGP54626A $(1 \mu \mathrm{M})$. Functional coupling to Kir3.1 + 3.2 channels shows current responses $\left(I_{\mathrm{Kir} 3.1}+3.2\right)$ to GABA $(100 \mu \mathrm{M}$ for 10 sec, white arrow), CGP54626A (1 $\mu \mathrm{M}$ for $60 \mathrm{sec}$, gray arrow), and GABA+CGP54626A (for $10 \mathrm{sec}$, black arrow) in transfected HEK293 cells. All results are representative of at least three independent experiments. Schematic representation of $\mathrm{GABA}_{\mathrm{B}(1)}$ (white) and GABA $\mathrm{B}_{\mathrm{B}(2)}\left(\right.$ gray $_{\text {) receptors: boxes represent }}$ the TMDs; LZ1 and LZ2 are shown in black. Where present, C-terminal histidine tags (his) are indicated. E, Surface targeting of WT and mutant $\mathrm{GABA}_{\mathrm{B}(1)}$ proteins expressed individually and in combination with WT and mutant $\mathrm{GABA}_{\mathrm{B}(2)}$. Intact cells $(S)$ and cell homogenates $(H)$ were photoaffinity-labeled with the membrane-impermeable, $\mathrm{GABA}_{\mathrm{B}(1)}$-specific antagonist $\left[{ }^{125} \mathrm{I}\right] \mathrm{CGP} 71872$ and subjected to SDS-PAGE. Labeled proteins were detected by autoradiography. The radioactivity incorporated into the surface $(S)$ and homogenate $(H)$ fraction was normalized to the respective amount of protein in each fraction before the percentage $\mathrm{S} / \mathrm{H}$ ratio was calculated.

signal of $\mathrm{GABA}_{\mathrm{B}(1)}$ has been replaced by the $\mathrm{GABA}_{\mathrm{B}(2)}$ sequence, yields functional receptors (Fig. 1D). For all subunit combinations tested, functional analysis does not reveal any differences between $\mathrm{G} \beta \gamma\left(\mathrm{I}_{\mathrm{Kir} 3.1}+3_{3.2}\right)$ and $\mathrm{G} \alpha_{\mathrm{qo} 5}$ signaling $\left(\Delta\left[\mathrm{Ca}^{2+}\right]_{\mathrm{i}}\right)($ Fig. $1 B, C, D)$. Photoaffinity labeling (Fig. $\left.1 E\right)$ studies confirm that WT GABA $\mathrm{B}_{\mathrm{B}(1)}$ targets to the cell surface in combination with $\mathrm{WT} \mathrm{GABA}_{\mathrm{B}(2)}(\mathrm{R} 1+\mathrm{R} 2)$ but not in combination with R2T749 (R1+ R2T749). R1K886, devoid of any putative ERR/R signal, is efficiently delivered to the cell surface when expressed alone (Fig. 1E). 


\section{The RSRR motif prevents surface trafficking of $\mathrm{GABA}_{\mathrm{B}(1)}$}

To further localize the signal preventing $\mathrm{GABA}_{\mathrm{B}(1 \mathrm{a})}$ surface expression, we sequentially truncated a total of 113 residues of its 960 amino acids $\mathrm{C}$ terminus (Fig. $2 A, B$ ). For functional studies, we coexpressed the resulting mutants with WT GABA $\mathrm{B}_{\mathrm{B}(2)}$ (positive control) or R2T749 to avoid shielding of the putative ERR/R signal (Fig. 2C). Our results with R2T749 coexpression show that functional activity (Fig. 2C) and surface trafficking (Figs. $2 F, 6 A$ ) are impaired when $<32$ amino acids are truncated from the $\mathrm{GABA}_{\mathrm{B}(1)} \mathrm{C}$ terminus (R1P928). Sequential truncation beyond $\mathrm{P}^{928}$ up to TMD7 (mutants R1L921 through R1I860) abrogates intracellular retention (Figs. $2 F, 6 A$ ), and functional expression is restored (Fig. $2 C$ ). We conclude that the information necessary for retention is located in a seven amino acid segment between $\mathrm{L}^{921}$ and $\mathrm{P}^{928}$, in the vicinity of the LZ1 (Fig. $2 A$ ). Known ERR/R motifs within this segment are RSR and RR because they match the consensus motives first identified in $\mathrm{K}_{\mathrm{ATP}}$ channels (Zerangue et al., 1999) and human invariant chain Iip33 polypeptides (Schutze et al., 1994).

The regions involved in coupling the mGlu receptors to G-proteins are thought to be the second/third intracellular loops and C-terminal domains (Pin et al., 1994; Francesconi and Duvoisin, 1998). Pharmacological analysis of C-terminal mGlu1 splice variants has shown that although the rank order of agonist potencies is identical, the potencies differ between variants (Flor et al., 1996). We therefore explored whether deletion of $\mathrm{C}$-terminal domains in both subunits changes the pharmacological profile of the R1I860+R2T749 receptor (Fig. 2D,E). $\left[{ }^{125} \mathrm{I}\right] \mathrm{CGP} 64213$ displacement curves with agonists [GABA, L-baclofen, 3-aminopropylphosphinic acid (APPA)] and antagonists (CGP54626A, CGP35348) are similar to those obtained with WT receptors. Similarly, concentration-response curves obtained in FLIPR analysis do not show significant differences compared with WT receptors (Fig. 2E). We conclude that C-terminal domains do not influence G-protein coupling, because this would likely result in altered agonist pharmacology.

To pinpoint the critical residues responsible for ERR/R, we used alanine-scanning mutagenesis to change each residue from $\mathrm{R}^{922}$ to $\mathrm{P}^{928}$ (Fig. $3 A$ ). When coexpressed with $\mathrm{R} 2 \mathrm{~T} 749$ to prevent shielding of the ERR/R signal, only mutation of $R^{922}$ (R1[소RHPP]), $\mathrm{R}^{924}$ (R1[RSARHPP]), and $\mathrm{R}^{925}$ (R1[RSRAHPP]) yielded functional receptors (Fig. $3 B$ ). The resulting motif, RXRR, matches both the RXR consensus defined for $\mathrm{K}_{\mathrm{ATP}}$ channels and the RR retention signal of Iip33 polypeptides. Although the $\mathrm{S}^{923} \rightarrow$ A mutation (R1[RARRHPP]) does not allow the assembly of functional receptors, signaling is obtained with the $S^{923} \rightarrow D$ mutation (R1[RDRRHPP]) (Fig. 3B). The latter replacement is therefore not permissible in the ERR/R signal, and the position between the two arginine residues cannot accommodate large side chains, similar as for the RXR motif in $\mathrm{K}_{\mathrm{ATP}}$ channels (Zerangue et al., 1999) and the cystic fibrosis transmembrane conductance regulator (Chang et al., 1999). Subunits with multiple mutations in the RSRR

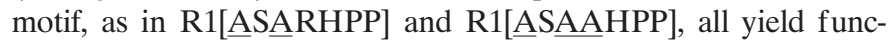
tional heteromeric receptors when coexpressed with the C-terminally truncated R2T749 subunit (Fig. 3B). Stressing the importance of the RSRR motif, we can rescue the nonfunctional combination R1+R2CR1 by inactivating the two ERR/R signals

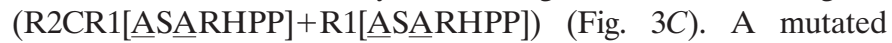
ERR/R signal allows for coupling not only to PLC (Fig. $3 B$ ) but also to Kir3.1 + 3.2 (Fig. 3D), revealing no differences in the competence to signal through $\mathrm{G} \alpha_{\mathrm{qo}}$ and $\mathrm{G} \beta \gamma$. Similarly, dose-response curves in FLIPR analysis do not reveal significant pharmacological differences

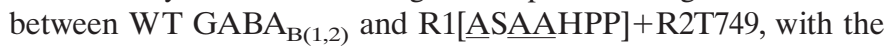
exception of the potency for APPA that is somewhat altered by the mutations $\left(\mathrm{pEC}_{50}\right.$ value $6.0 \pm 01$ vs $6.7 \pm 0.05$ for $\mathrm{WT}$ ) (Fig. $3 E$ ). The R1+R2T749 subunit combination with an active ERR/R signal is not functional (Fig. $3 E$ ). The above data suggest that mutation of the RSRR motif enables $\mathrm{GABA}_{\mathrm{B}(1)}$ to escape from the ER. We directly analyzed the surface localization of $\mathrm{GABA}_{\mathrm{B}(1)}$ mutants in photoaffinity labeling and immunofluorescence experiments (Figs. $3 F, 6 A)$. When expressed by themselves, mutants R1[ASRRHPP],

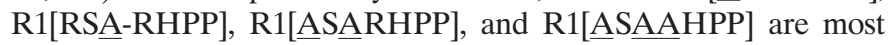
efficiently transported to the cell surface. The arginine residues thus cooperate in mediating full ER retention. R1[RSRAHPP] and R1[RDR-RHPP] show relatively inefficient escape (low surface expression levels), indicating that the mutated ERR/R motif is not fully functional and allows some leakage. In R2T749 coexpression experiments, efficient trafficking of alanine mutants to the surface (Fig. $3 F$ ) always correlates with functional responses (Fig. 3B). In general, coexpression of R2T749 with alanine mutants increased surface trafficking relative to the mutants expressed individually (Fig. $3 F$ ). Subunit coexpression may stabilize the heteromeric receptor complex during export from the secretory apparatus or at the cell surface.

In summary, deletion and alanine-scanning analysis indicate that the RSRR motif is sufficient to prevent escape of the $\mathrm{GABA}_{\mathrm{B}(1)}$ protein from the early secretory apparatus and that no other ERR/R signal is operative. Importantly, surface targeting of RSRR mutants does not confer homomeric function (data not shown). In the heteromeric receptor complex, $\mathrm{GABA}_{\mathrm{B}(2)}$ therefore not only mediates surface trafficking but also participates in intracellular signaling. The dominant role of the RSRR signal in $\mathrm{GABA}_{\mathrm{B}(1)}$ on cell surface expression is intriguing. Remarkably, $\mathrm{GABA}_{\mathrm{B}(2)}$, which efficiently targets to the cell surface by itself, contains several putative ERR/R signals in its $\mathrm{C}$ terminus as well (RHR, RLR) (Fig. 4A). Possibly these signals are inactive because the sequence context prevents their exposure in the ER. Alternatively, ER resident proteins other than $\mathrm{GABA}_{\mathrm{B}(1)}$ mask them.

\section{C-terminal $\mathrm{GABA}_{\mathrm{B}(2)}$ sequences are sufficient to mask the ERR/R signal of $\mathrm{GABA}_{\mathrm{B}(1)}$}

The above data indicate that $\mathrm{C}$-terminal sequences of $\mathrm{GABA}_{\mathrm{B}(2)}$ antagonize the $\mathrm{GABA}_{\mathrm{B}(1)} \mathrm{ERR} / \mathrm{R}$ signal. We therefore made serial truncations in the $\mathrm{C}$ terminus of $\mathrm{GABA}_{\mathrm{B}(2)}$ to map the shielding sequences (Fig. $4 A, B, C, F$ ). The data show that the C-terminal 130 residues, including seven residues of LZ2, can be removed without loss of function (R1+R2E811) (Fig. 4C). Because the ERR/R signal is in close proximity of the $C$ terminus of LZ1, $\mathrm{GABA}_{\mathrm{B}(2)}$ sequences directly complementary to the ERR/R signal $\left(\mathrm{T}^{823}\right.$ through $\mathrm{I}^{826}$ ) (Fig. $4 A$ ) are unnecessary for its shielding. Additional truncation of LZ2 (R2L791) (Fig. 4C) results in loss of function, suggesting that the coiled-coil interaction between $\mathrm{GABA}_{\mathrm{B}(1)}$ and $\mathrm{GABA}_{\mathrm{B}(2)}$ is destabilized to the point where no shielding is possible anymore. The LZ2 residues between $\mathrm{L}^{791}$ and $\mathrm{E}^{811}$ therefore are important for engaging LZ1 into a coiled-coil interaction that propagates a $\mathrm{C}$-terminal conformation that neutralizes the ERR/R signal.

Expression of the otherwise nonfunctional R1+R2T749 combination together with the $\mathrm{C}$ terminus of $\mathrm{GABA}_{\mathrm{B}(2)}(\mathrm{CR} 2)$ (Fig. $4 B)$ results in complementation and recovery of intracellular signaling (Fig. 4D). The concentration-response curves in 
A LVVLFVPKMRRLITRGEWQSETQDTMKTGSSTNNNEEET 886
SRLLEKENRELEKIIAEKEERVSELRHQLQSRQQLRSRR 925 HPPTPDPSGLPR TPSEPDRLSCDGSRVHLLYK 960

B

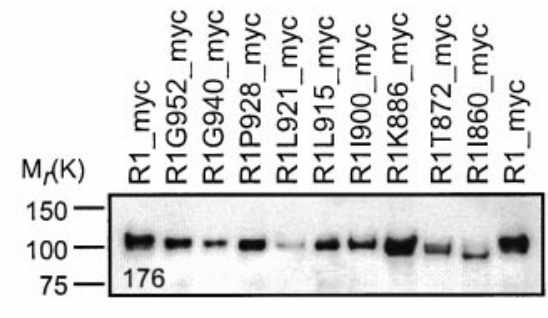

C

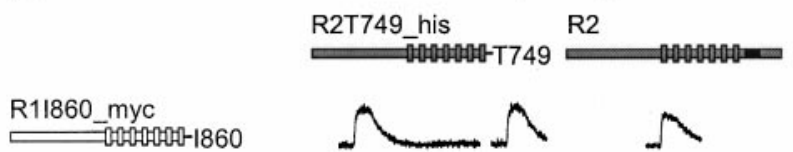

R1T872_myc R1T872_myc

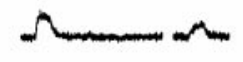

N

R1K886_myc

R1L915_myc

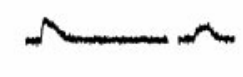

$\Omega$

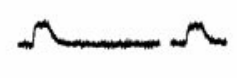

R1L921_myc

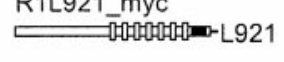

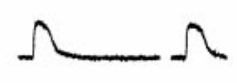

R1P928_myc

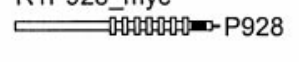

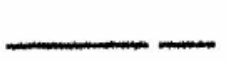

R1G940_myc

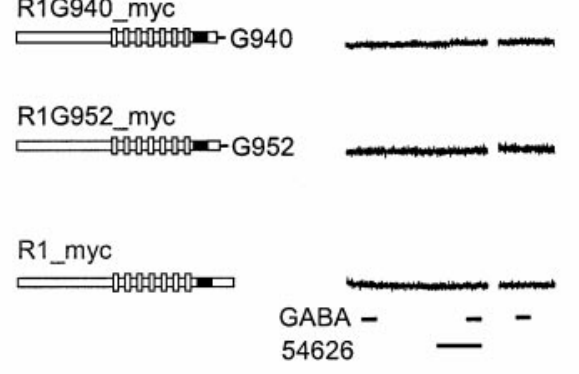

D
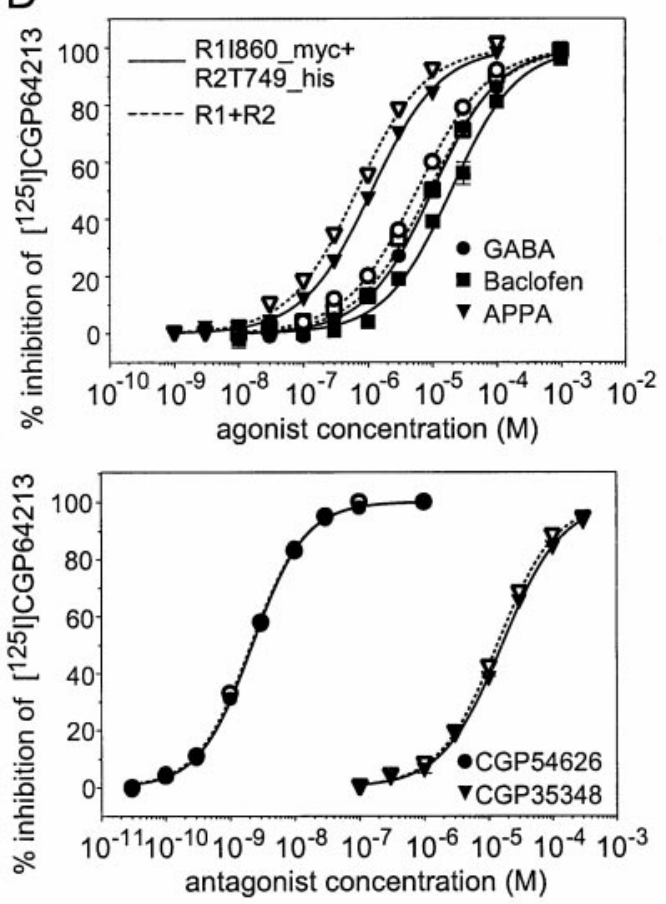

E

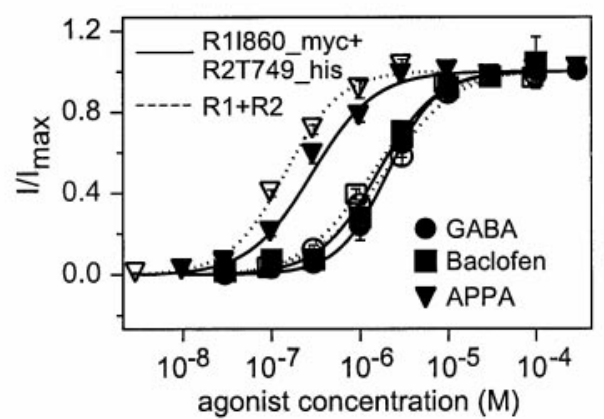

$\Lambda$
F

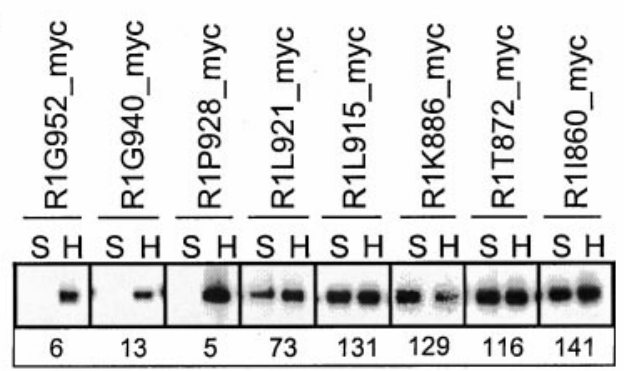

Figure 2. Progressive $\mathrm{C}$-terminal $\mathrm{GABA}_{\mathrm{B}(1)}$ deletion mutants indicate that residues between $\mathrm{P}^{928}$ and $\mathrm{L}^{921}$ impair surface expression. $A$, C-terminal domain of $\mathrm{GABA}_{\mathrm{B}(1)}$ with LZ1 ( $\mathrm{E}^{884}-\mathrm{S}^{917}$, shaded). The C-terminal residues of the deletion mutants are shown in white letters. The RSRR sequence encoding a putative ERR/R signal in close proximity to LZ1 is boxed. $B$, Immunoblot analysis of $\mathrm{GABA}_{\mathrm{B}(1 \mathrm{a})}$ deletion mutants with antibody 176 . All mutants were tagged with the myc epitope. $C$, Functional expression of $\mathrm{GABA}_{\mathrm{B}(1 \mathrm{a})}$ deletion mutants together with C-terminally truncated GABA $\mathrm{B}_{(2)}(\mathrm{R} 2 \mathrm{~T} 749$-his) to prevent shielding of the putative ERR/R. As a control, all $\mathrm{GABA}_{\mathrm{B}(1)}$ mutants yield functional responses together with $\mathrm{WT}_{\mathrm{GABA}} \mathrm{B}_{\mathrm{B}(2)}\left(\mathrm{R}_{2}\right)$. D, Binding pharmacology of a C-terminally truncated receptor (R1I860+R2T749, closed symbols) and WT GABA ${ }_{\mathrm{B}(1 \mathrm{a}, 2)}\left(\mathrm{R} 1+\mathrm{R} 2\right.$, open symbols) receptors. Inhibition of [ $\left.{ }^{125} \mathrm{I}\right] \mathrm{CGP} 64213$ binding by agonists (GABA, L-baclofen, APPA) and antagonists (CGP54626A, CGP35348) using membranes from transfected HEK293 cells is shown. The affinities for agonists and antagonists do not differ significantly between mutant and WT receptors. The pIC 50 values for R1+R2T749_his and R1+R2 are as follows: GABA, $5.0 \pm 0.02$ and 5.2 \pm 0.02; L-baclofen, $4.7 \pm 0.03$ and $5.1 \pm 0.03$; APPA, $5.9 \pm 0.01$ and 6.2 \pm 0.03 ; CGP54626A, 8.7 \pm 0.01 and 8.7 \pm 0.01 ; CGP35348, $4.8 \pm 0.01$ and $4.9 \pm 0.01$, respectively. Results from typical experiments performed in triplicate are shown. Immunoblotting and photoaffinity labeling verified $\mathrm{GABA}_{\mathrm{B}}$ protein expression (data not shown). E, FLIPR analysis. Concentration-response curves for agonists at WT receptors (R1+R2, open symbols) and R1I860+R2T749 ( filled symbols). Data points show average and SEM of relative fluorescence changes normalized to their maximum $\left(I / I_{\max }\right)$. Lines are Hill equations fitted to the data points. $\mathrm{pEC}_{50}$ values for GABA, $\mathrm{L}$-baclofen, and APPA are $5.8 \pm 0.1$ and $5.7 \pm 0.1,5.9 \pm 0.1$ and $5.7 \pm 0.05,6.7 \pm$ 0.05 and $6.5 \pm 0.05$ for WT and R1I860+R2T749 receptors, respectively (mean \pm SEM; $n=4-8$ ). Hill coefficients for GABA, L-baclofen, and APPA are $1.1 \pm$ 0.2 and $1.3 \pm 0.2,1.1 \pm 0.2$ and $1.3 \pm 0.2,1.4 \pm 0.3$ and $1.2 \pm 0.2$ for WT and R1I860+R2T749 receptors, respectively (mean \pm SEM; $n=4-8)$. $F$, Surface targeting of individually expressed $\mathrm{C}$-terminal $\mathrm{GABA}_{\mathrm{B}(1)}$ deletion mutants. 

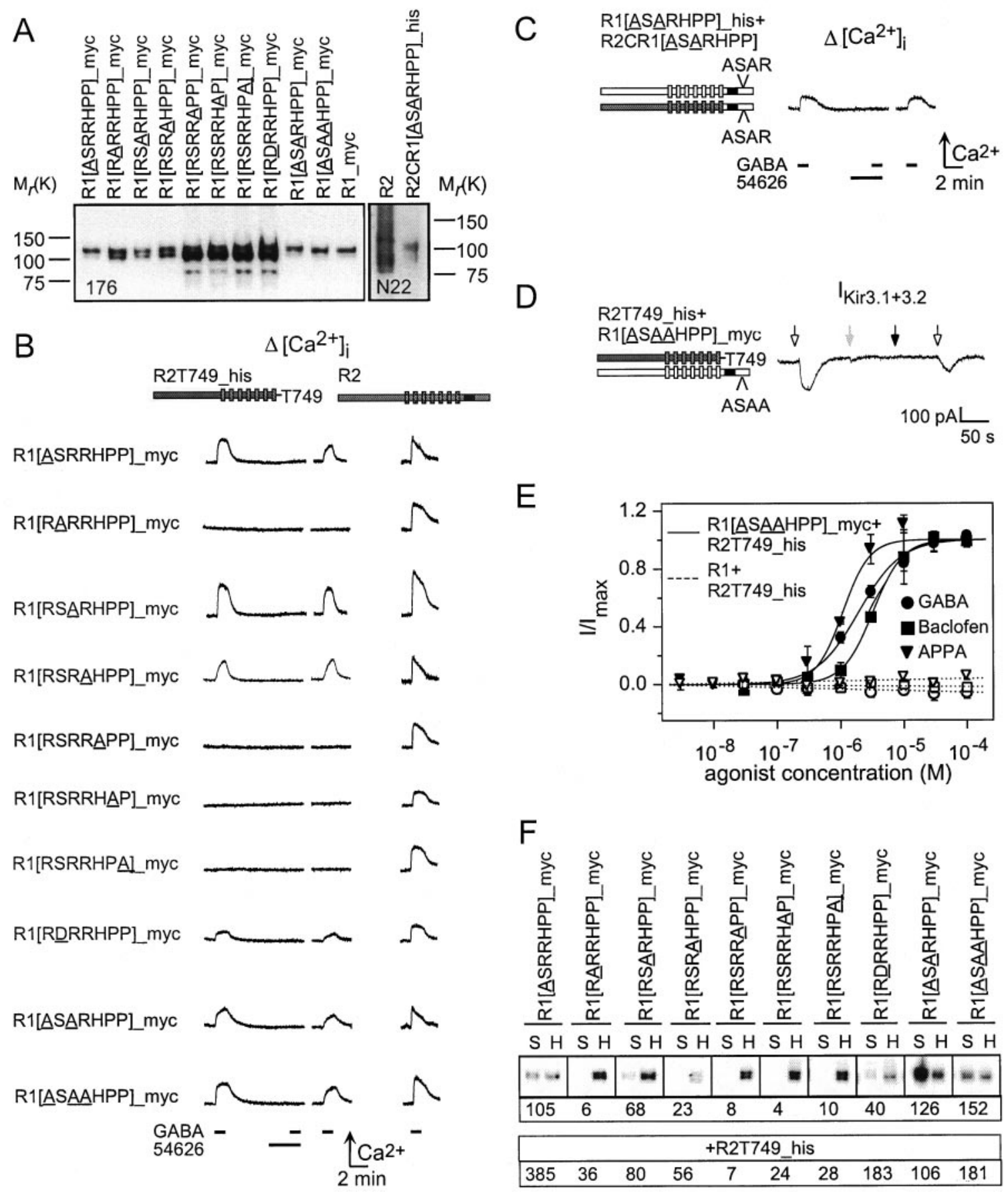

Figure 3. Alanine scanning of the $\mathrm{R}^{922} \mathrm{SRRHPP}$ sequence identifies the $\mathrm{GABA}_{\mathrm{B}(1)}$ ERR/R motif. $A$, Immunoblot analysis of $\mathrm{GABA} \mathrm{B}(1 \mathrm{a})$ alanine mutants with antibody 176. All mutants were tagged with the myc epitope. $B$, Functional expression of GABA $\mathrm{B}_{\mathrm{B}(1)}$ alanine mutants together with C-terminally truncated $\mathrm{GABA}_{\mathrm{B}(2)}\left(\mathrm{R} 2 \mathrm{~T} 749\right.$ his) to prevent shielding of the ERR/R. As a control, all GABA $\mathrm{B}_{\mathrm{B}(1)}$ alanine mutants yield functional responses when expressed together with $\mathrm{WT}_{\mathrm{GABA}} \mathrm{BA}_{(2)}(R 2)$. $C$, Functional rescue of the $\mathrm{R} 1+\mathrm{R} 2 \mathrm{CR} 1$ receptor by mutation of $\mathrm{RR}^{922 / 924} \rightarrow \mathrm{AA}^{2}$ in the two $\mathrm{GABA}_{\mathrm{B}(1)}$ C termini. $D$, Kir3.1 + 3.2 mediated current responses in transfected HEK293 cells coexpressing WT and mutated (RRR $\left.{ }^{922 / 924 / 925} \rightarrow \mathrm{AAA}\right)$ $\mathrm{GABA}_{\mathrm{B}(1)}$ receptors together with R2T749 his, demonstrating competence to signal through G $\beta \gamma$. E, FLIPR analysis. Agonist concentration-response curves at the same subunit combinations as in $D$, demonstrating competence to signal through $\mathrm{G} \alpha$. For the triple alanine mutant ( filled symbols), $\mathrm{pEC}_{50}$ values (Hill coefficients) for GABA, L-baclofen, and APPA are 5.7 $\pm 0.1(1.3 \pm 0.2), 5.5 \pm 0.1(1.8 \pm 0.3)$, and $6.0 \pm 0.1(2.1 \pm 0.4)$, respectively (mean \pm $\mathrm{SEM} ; n=4) . F$, Surface targeting of double and triple mutants within the $\mathrm{R}^{922}$ SRRHPP sequence. For reference, the percentage $\mathrm{S} / \mathrm{H}$ values of the alanine mutants in combination with R2T749_his, shown in $B$, are also listed.

FLIPR analysis show similar pharmacological properties as for $\mathrm{WT} \mathrm{GABA}_{\mathrm{B}(1,2)}$ (Fig. 4E). In contrast, coexpression of CR2 with $\mathrm{R} 1+\mathrm{R} 2 \mathrm{CR} 1$ does not rescue functionality (Fig. 4D). This indicates that CR2 is unable to mask two ERR/R signals in a putative heteromeric assembly, possibly because of sterical hindrance. The
$\mathrm{R} 1+\mathrm{CR} 2$ combination is targeted to the cell surface (Fig. $4 F$ ) but is signaling incompetent (Fig. 4D), demonstrating that cell surface release of monomeric WT $\mathrm{GABA}_{\mathrm{B}(1)}$ is not sufficient for $\mathrm{G}$-protein coupling. Because $\mathrm{C}$-terminally truncated subunits assemble functional heteromeric complexes (e.g., R1I860+R2T749) 
A

R1 LVVLFVPKMRRLITRGEWQSETQDTMKTGSSTNNNEEEK 886 R2 TNPDAATQNRRFQFTQNQKKEDSKTSTSVTSVNQASTSR 787

R1 SRLLEKENRELEKIIAEKEERVSELRHQLQSRQQIRSRR 925 R2 LEGLQSENFRLRMKITELDKDLEEVTMQLQDTPEKTTYI 826

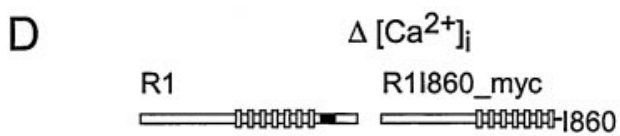

CR2_ha

R2T749 his+

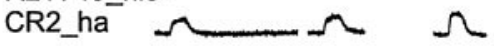

R2CR1_his+

CR2 ha
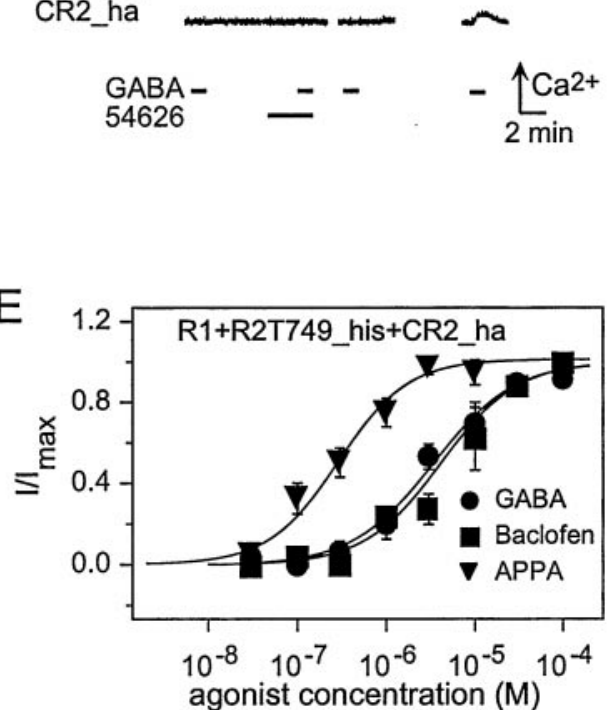

$\mathrm{F}$

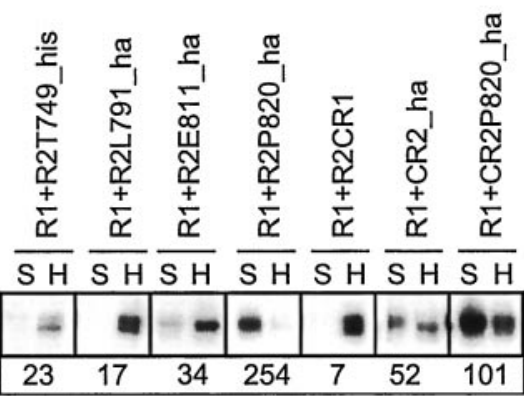

Figure 4. Influence of the $\mathrm{GABA}_{\mathrm{B}(2)} \mathrm{C}$-terminal domain on $\mathrm{GABA}_{\mathrm{B}(1)}$ surface expression and function. $A$, The $\mathrm{C}$-terminal domains of $\mathrm{GABA} \mathrm{B}_{(1)}$ and $\mathrm{GABA}_{\mathrm{B}(2)}$ with LZ1 ( $\mathrm{E}^{884}-\mathrm{S}^{917}$, shaded $)$ and LZ2 $\left(\mathrm{T}^{785}-\mathrm{D}^{818}\right.$, shaded $)$ are shown. The C-terminal residues of GABA $\mathrm{B}_{\mathrm{B}(2)}$ deletion mutants are depicted in white letters. The RSRR motif and RXR consensus sequences in $\mathrm{GABA}_{\mathrm{B}(2)}$ are boxed. $B$, Immunoblot analysis of $\mathrm{GABA} \mathrm{B}_{(2)}$ mutants with $\mathrm{N}$-terminal (N22) and C-terminal (C22) antibodies. The antibodies do not recognize mutant CR2P820 $\left(\mathrm{R}^{714}\right.$ through $\left.\mathrm{P}^{820}\right)$, which are missing $\mathrm{N}$ - and $\mathrm{C}$-terminal epitopes. Expression of CR2P820 was confirmed in immunofluorescence studies with anti-HA antibodies (data not shown). $C$, Functional expression of C-terminally truncated $\mathrm{GABA}_{\mathrm{B}(2)}$ receptors together with $\mathrm{WT} \mathrm{GABA}_{\mathrm{B}(1)}$. As a control, all $\mathrm{GABA}_{\mathrm{B}(2)}$ mutants yield functional responses when expressed together with R1860_myc, which is devoid of the domain containing the RSRR signal. $D$, The C-terminal domain of GABA ${ }_{\mathrm{B}(2)}\left(\mathrm{CR}_{2}\right.$, $\mathrm{R}^{714}$ through $\mathrm{L}^{941}$ ), expressed as a membrane-bound protein, rescues the otherwise functionally inert R1+R2T749 subunit combination in trans. CR2 is not able to mask the RSRR signal when two $\mathrm{GABA}_{\mathrm{B}(1)} \mathrm{C}$ termini are present (R2CR1+R1). E, FLIPR analysis. Agonist concentration-response curves for

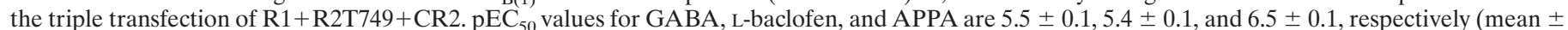
SEM; $n=4)$. Hill coefficients for GABA, L-baclofen, and APPA are $0.9 \pm 0.1,1.0 \pm 0.2$, and $1.1 \pm 0.2$, respectively (mean \pm SEM; $n=4)$. $F$, Surface targeting of $\mathrm{GABA}_{\mathrm{B}(1)}$ in combination with $\mathrm{C}$-terminally truncated $\mathrm{GABA}_{\mathrm{B}(2)}$, R2CR1, and the C-terminal GABA $\mathrm{B}_{\mathrm{B}(2)}$ fragments $\mathrm{CR} 2$ and $\mathrm{CR} 2 \mathrm{P} 820$.

(Fig. $2 C, E$ ), it follows that in the dimer the TMDs of $\mathrm{GABA}_{\mathrm{B}(2)}$ are involved in addressing the effector system. A truncated CR2 fragment with a deletion of the 121 residues $\mathrm{C}$ terminal of the zipper domain, CR2P820, very efficiently exports WT GABA $\mathrm{B}(1)_{\text {to }}$ the cell surface (Figs. $4 F, 6 A$ ). Therefore the shielding information provided by the $\mathrm{GABA}_{\mathrm{B}(2)} \mathrm{C}$ terminus resides between TMD7 and $\mathrm{P}^{820}$.
We previously observed functional responses in a minor fraction of transfected HEK293 cells expressing $\mathrm{GABA}_{\mathrm{B}(1)}$ or $\mathrm{GABA}_{\mathrm{B}(2)}$ alone (Kaupmann et al., 1998a,b). We speculated that homomeric $\mathrm{GABA}_{\mathrm{B}(1)}$ responses were the consequence of forcing receptors to their effectors at the cell surface, because of the artificially high expression levels observed in heterologous cells. 
The lack of functional responses obtained with monomeric $\mathrm{GABA}_{\mathrm{B}(1)}$ expressed at the cell surface (e.g., R1CR2, R1K886, and R1+CR2P820) makes this explanation less likely. Rare responses obtained with $\mathrm{GABA}_{\mathrm{B}(1)}$ and $\mathrm{GABA}_{\mathrm{B}(2)}$ may depend on additional factors that are limiting or absent in most HEK293 cells.

\section{C-terminal coiled-coil interaction is involved in, but not absolutely necessary for, masking the RSRR signal}

One structural feature that is characteristic of $\mathrm{GABA}_{\mathrm{B}}$ receptor subunits, and not shared by other family 3 GPCRs, is the presence of leucine zippers in their $\mathrm{C}$ termini. The previous experiments demonstrate that a C-terminal fragment of $\mathrm{GABA}_{\mathrm{B}(2)}, \mathrm{CR} 2 \mathrm{P} 820$, which includes LZ2, can traffic WT GABA $\mathrm{B}_{\mathrm{B}(1)}$ to the cell surface (Fig. $4 F$ ). The close proximity of the RSRR motif to the LZ1 (Fig. 5A) suggests that the ERR/R signal is inactivated upon coiled-coil dimerization. To test the role of the leucine zippers on targeting and function, we deleted LZ1 (R1 $\Delta \mathrm{LZ1}$ ) and LZ2 (R2 $\Delta$ LZ2) from the WT subunits (Fig. 5A,B). Surprisingly, LZ1 deletion does not impair functional assembly in $\mathrm{R} 1 \Delta \mathrm{LZ} 1+\mathrm{R} 2$ (Fig. $5 B$ ). However, deletion of LZ1 in R1 $\Delta \mathrm{LZ1}$ may alter the structural context in which the ERR/R signal is placed and render it inactive, as has been observed for the RXR motif in Kir6.2 (Zerangue et al., 1999). This is supported by the fact that the $\mathrm{R} 1 \Delta \mathrm{LZ} 1+\mathrm{R} 2 \mathrm{~T} 749$ receptor, where no $\mathrm{GABA}_{\mathrm{B}(2)}$ shielding is provided, is functional (Fig. $5 B$ ). Photoaffinity labeling (Fig. $5 F$ ) and surface immunofluorescence (Fig. 6A) experiments demonstrate that R1 $\Delta \mathrm{LZ1}$ is indeed efficiently released to the cell surface. Conformational changes imposed by the deletion are therefore responsible for $\mathrm{R} 1 \Delta \mathrm{LZ} 1$ surface delivery, rather than a shielding of the ERR/R signal through coiled-coil independent interactions. Deletion of the zipper in $\mathrm{GABA}_{\mathrm{B}(2)}$ is sufficient to prevent functional assembly in combination with WT GABA $\mathrm{G}_{\mathrm{B}(1)}$ (R2 $\Delta$ LZ2+R1) (Fig. 5B), suggesting that preventing the coiledcoil interaction impairs masking of the ERR/R signal. R2 $\Delta \mathrm{LZ2}$ does constitute functional heterodimers with $\mathrm{GABA}_{\mathrm{B}(1)}$ subunits that have an impaired (R2 $\Delta \mathrm{LZ} 2+\mathrm{R} 1 \Delta \mathrm{LZ} 1)$ (Fig. $5 B$ ) or missing (R2 $\Delta$ LZ2+R1I860) (Fig. 5B) ERR/R signal, demonstrating that the introduced mutation does not generally affect functionality.

We further tested the roles of the zipper domains by exchanging them between subunits. The resulting mutants R1LZ2 and R2LZ1 produce functional receptors in all combinations tested (Fig. 5C). Small responses obtained with R1LZ2+R2T749 demonstrate that replacement of LZ1 by LZ2 imposes conformational constraints that impair proper functioning of the RSRR motif. The R1LZ2 receptor expressed alone is not detectable at the surface by immunostaining, suggesting that a small amount of mutant protein escapes the ER (Fig. 6A). However, this leakage of R1LZ2 from the ER may explain the coupling obtained in combination with WT GABA ${ }_{\mathrm{B}(2)}(\mathrm{R} 1 \mathrm{LZ} 2+\mathrm{R} 2)($ Fig. $5 C)$, in the absence of coiled-coil interaction between the two LZ2 domains (Kammerer et al., 1999). The R2LZ1+R1 combination with LZ1 in both subunits yields barely functional receptors (Fig. 5C), again in the absence of coiled-coil interaction between the two LZ1 domains (Kammerer et al., 1999). Because this receptor combination consistently yields tiny responses, we conclude that significant but not absolutely tight shielding is taking place. R1LZ2+R2LZ1 assembles a highly functional receptor, demonstrating that swapped zippers enable efficient surface targeting (Fig. 5B).

Because the leucine zipper deletion and exchange experiments were not absolutely conclusive because of possible conforma- tional alterations forced by the changes, we decided to destabilize the coiled-coil interaction between $\mathrm{GABA}_{\mathrm{B}(1)}$ and $\mathrm{GABA}_{\mathrm{B}(2)}$ by introducing proline mutations. Leucine zippers form amphipathic $\alpha$-helices that coil around each other in a left-handed supertwist. The sequences of coiled coils are characterized by a heptad repeat of seven residues denoted $a-g$ (Fig. $5 A$ ). The stability of a coiled coil is determined by interactions between residues in the hydrophobic interface (positions $a$ and $d$ ) (Lupas, 1996; Malashkevich et al., 1996). We therefore introduced proline residues, which are expected to break helices, at three of these critical positions in LZ1 (R1[PPP]) and LZ2 (R2[PPP]) (Fig. 5A). In contrast to $\mathrm{R} 1 \Delta \mathrm{LZ} 1$ and $\mathrm{R} 1 \mathrm{LZ} 2$, the $\mathrm{R} 1[\mathrm{PPP}]$ subunit is very tightly retained in the ER, as shown by the lack of responses on coexpression with R2T749, where no shielding of the ERR/R is provided (R1[PPP]+R2T749) (Fig. 5D). This is confirmed in both surface photoaffinity (Fig. $5 F$ ) and immunofluorescence (Fig. 6A) labeling experiments. Clearly, surface trafficking is not inherent to R1[PPP], and its ERR/R signal is still fully active. As expected, receptor function is recovered by replacing $\mathrm{R} 2 \mathrm{~T} 749$ with WT GABA $\mathrm{B}_{(2)}(\mathrm{R} 1[\mathrm{PPP}]+\mathrm{R} 2)($ Fig. $5 D)$. R2[PPP] is able to form functional receptors with WT $\mathrm{GABA}_{\mathrm{B}(1)}$, demonstrating that the ability to mask the ERR/R signal is retained after mutation of LZ2 (Fig. 5D). As a control, R2[PPP] also forms functional assemblies with R1I860, where no ERR/R signal is operative (Fig. 5D). The R1[PPP]+R2[PPP] combination, where $\alpha$-helices are impaired in both leucine zippers, is not expected to undergo significant coiled-coil interaction (Fig. 5D,E). Nevertheless, R1[PPP]+R2[PPP] exhibits functional responses, emphasizing that in the heteromer the coiled-coil interaction is not absolutely necessary for shielding of the RSRR motif. The agonist pharmacology of R1[PPP]+R2[PPP] is reminiscent of that of WT receptors (Fig. 5E).

Altogether, the experiments with mutated leucine zipper domains led us to conclude that (1) LZ1 is necessary for exposure of the RSRR motif and (2) the coiled-coil interaction between the two subunits is involved in, but not absolutely necessary for, shielding the ERR/R signal.

\section{The RSRR signal is recognized in neurons}

We next wanted to study whether the RSRR signal was active in primary neurons. Because $\mathrm{GABA}_{\mathrm{B}(1)}$ and $\mathrm{GABA}_{\mathrm{B}(2)}$ are expressed in virtually all neurons (Marshall et al., 1999), we were unable to perform experiments in the absence of endogenous $\mathrm{GABA}_{\mathrm{B}}$ protein. Although this supposedly complicates analysis in neurons, overexpression of the heterologous proteins by the cytomegalus virus promoter should lead to a saturation of the targeting machinery. This presumably overrides any possible influence on targeting by endogenous $\mathrm{GABA}_{\mathrm{B}}$ subunits, and therefore the mutant proteins are expected to exhibit their inherent targeting phenotype. In good agreement with this assumption, the targeting of WT and mutant GABA $_{\mathrm{B}}$ receptors in HEK293 cells (Fig. 6A) are mirrored in transfected cerebellar neurons (Fig. $6 B)$. Although $\mathrm{GABA}_{\mathrm{B}(1)}$ is retained intracellularly when expressed alone (R1) (Fig. 6B), it is directed to the cell surface when its ERR/R signal is inactivated by mutagenesis (R1[ASARHPP]) (Fig. $6 B$ ) or when expressed together with WT $\mathrm{GABA}_{\mathrm{B}(2)}(\mathrm{R} 1+\mathrm{R} 2)$ (Fig. 6B).

\section{$\mathrm{Ca}^{2+}$-sensing and $\mathrm{mGlu}$ receptors do not support surface expression of $\mathrm{GABA}_{\mathrm{B}(1)}$}

Targeting information is associated with the carboxyl tails of many neurotransmitter receptors and ion channels. It is therefore 


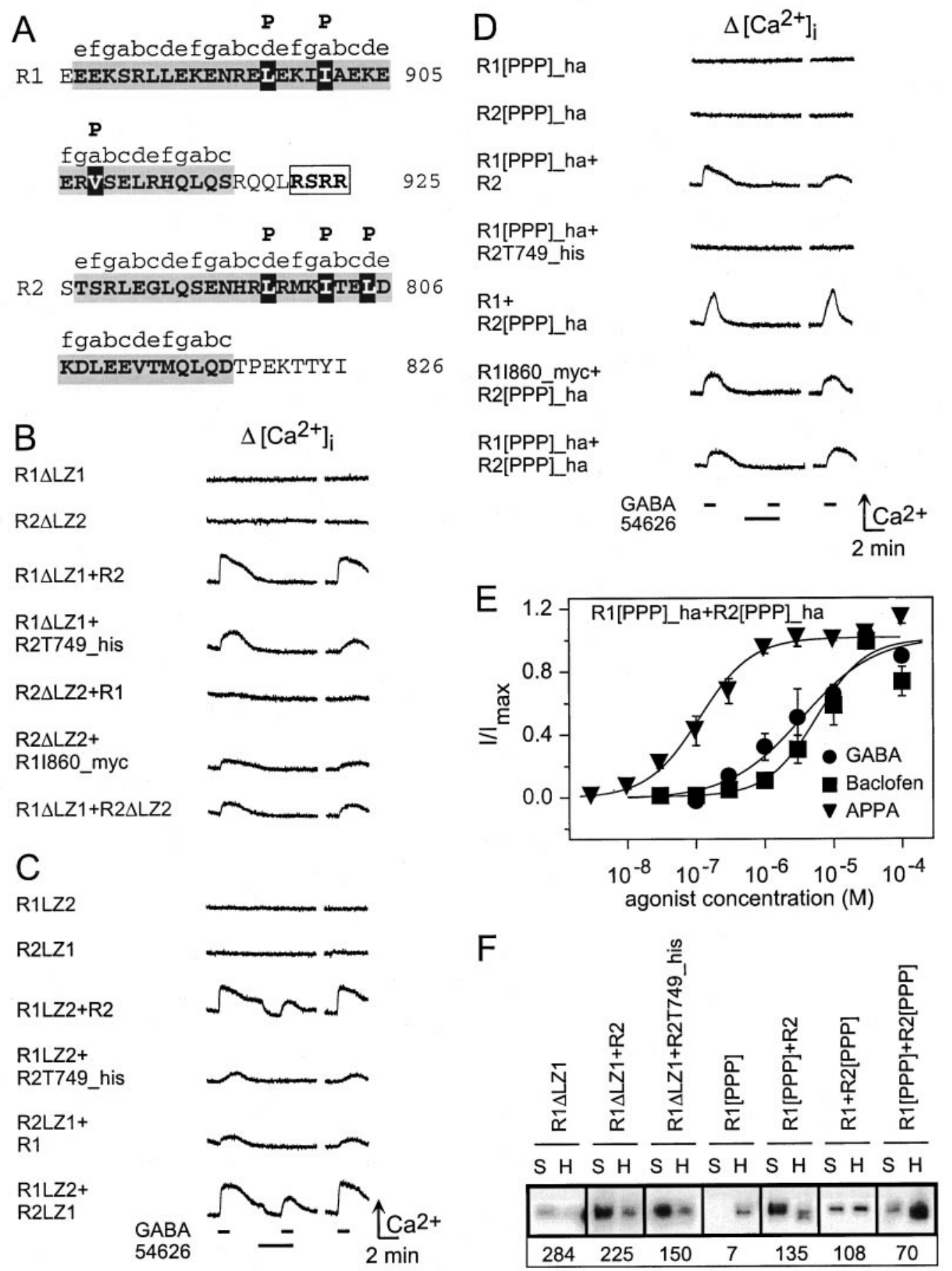

Figure 5. Functional analysis and surface expression of leucine zipper point, exchange, and deletion mutants. $A$, The sequences of the predicted $\mathrm{GABA}_{\mathrm{B}(1)}(R 1)$ and $\mathrm{GABA}_{\mathrm{B}(2)}(R 2)$ coiled-coil domains (shaded) are characterized by a heptad repeat of seven residues denoted $a-g$, with a 3,4-hydrophobic repeat of mostly apolar residues at positions $a$ and $d$. Proline mutations were introduced at the $\mathrm{L}^{897} \mathrm{I}^{901} \mathrm{~V}^{908}$ and $\mathrm{L}^{798} \mathrm{I}^{802} \mathrm{~L}^{805}$ core residues of $\mathrm{GABA}_{\mathrm{B}(1)}$ and $\mathrm{GABA}_{\mathrm{B}(2)}$, respectively. The ERR/R signal, spaced by four residues from LZ1, is boxed. B, Functional analysis of LZ1 $(R 1 \Delta L Z 1)$ and LZ2 (R2ALZ2) deletion mutants. C, Functional analysis of LZ1 (R2LZ1) and LZ2 (R1LZ2) exchange mutants. D, Functional analysis of LZ1 R1[PPP] and LZ2 R2[PPP] point mutants. E, FLIPR analysis. Agonist concentration-response curves for $R 1[P P P]+R 2[P P P]$. pEC f $_{50}$ values for GABA, L-baclofen, and APPA are $5.4 \pm 0.1,5.2 \pm 0.1$, and $6.8 \pm 0.05$, respectively (mean \pm SEM; $n=4$ ). Hill coefficients for GABA, L-baclofen, and

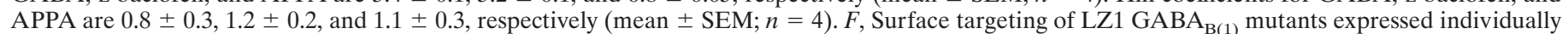
and in combination with WT and mutated $\mathrm{GABA}_{\mathrm{B}(2)}$. Expression of all mutants was verified on immunoblots (data not shown).

tempting to speculate that proteins other than $\mathrm{GABA}_{\mathrm{B}(2)}$ recognize and shield the $\mathrm{GABA}_{\mathrm{B}(1)}$ RSRR signal. Because coiled-coil interaction does not appear to be an absolute requirement to mask the ERR/R signal, these proteins may not necessarily contain leucine zippers. The RXR consensus is present in cyto- plasmic domains of various transmembrane proteins. For example, it is found in the C-terminal domains of most mGlu receptors, with the exception of mGlu 2 and mGlu3. It was claimed that mGlu4 receptors, which form homodimers and are structurally related to $\mathrm{GABA}_{\mathrm{B}}$ receptors, could act as a chaperone for 

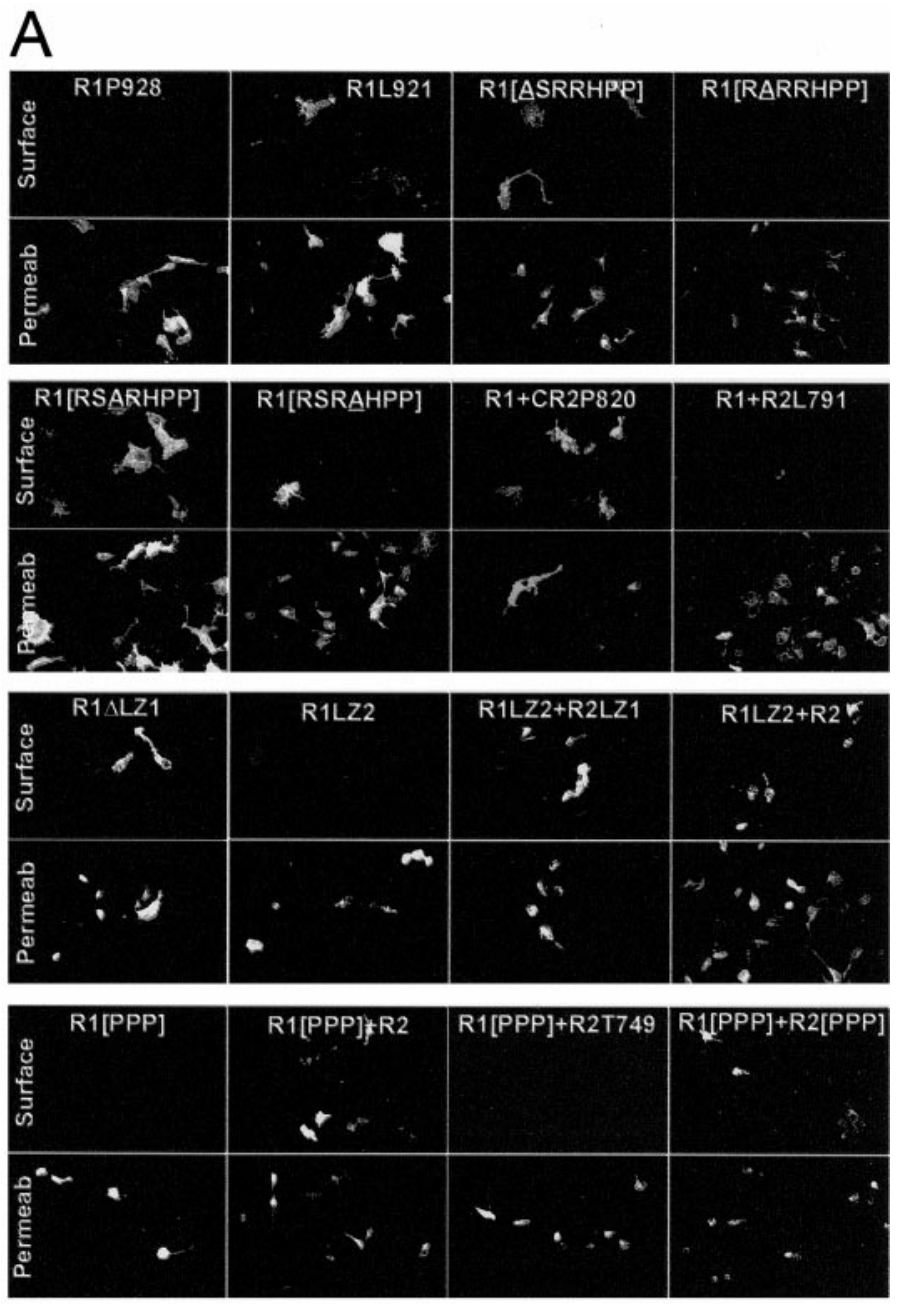

B

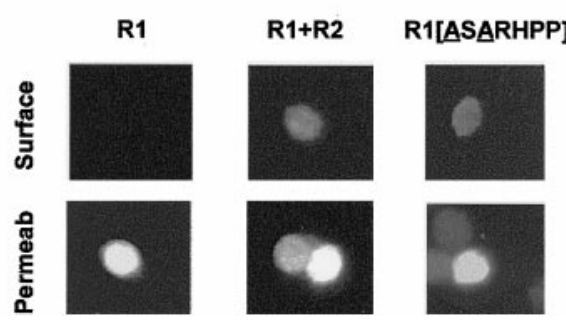

Figure 6. Surface expression of myc- and HA-tagged $\mathrm{GABA}_{\mathrm{B}}$ receptor mutants. $A$, Surface expression in transfected HEK293. The C-terminal deletion mutant R1L921 is expressed at the cell surface, whereas R1P928 is retained intracellularly. Substitution of alanine for $R^{922}$ (R1[ASRRHPP]), $\mathrm{R}^{924}$ (R1[RSARHPP]), and to a lesser extent $\mathrm{R}^{925}$ $(R 1[R S R A H P P])$ results in surface expression of $\mathrm{GABA}_{\mathrm{B}(1)}$, whereas substitution of $\mathrm{S}^{923}$ (R1 [RARRHPP]) does not affect intracellular retention. A C-terminal fragment of $\mathrm{GABA}_{\mathrm{B}(2)}$ encoding residues $\mathrm{R}^{714}$ through $\mathrm{P}^{820}(\mathrm{CR} 2 \mathrm{P} 820)$ efficiently traffics WT $\mathrm{GABA}_{\mathrm{B}(1)}$ to the plasma membrane. R2L791 with a more extensive C-terminal deletion is unable to deliver WT GABA $\mathrm{B}_{\mathrm{B}(1)}$ to the surface. Removal of the $\mathrm{LZ1}$ is sufficient to direct $\mathrm{R} 1 \Delta \mathrm{LZ} 1$ to the cell surface, indicating that $\mathrm{LZ1}$ is required for correct exposure of the ERR/R signal. R1LZ2 does not reveal surface immunoreactivity but is detectable at the plasma membrane on coexpression with either R2LZ1 or WT GABA $\mathrm{B}_{(2)}$. R1[PPP] does not show significant surface immunoreactivity when expressed alone but is targeted to the plasma membrane on coexpression with either $\mathrm{WT} \mathrm{GABA}_{\mathrm{B}(2)}$ or R2[PPP]. Coexpression with R2T749 is insufficient to traffic R1[PPP] to the cell surface, because no shielding of the fully functional ERR/R in $\mathrm{R} 1[\mathrm{PPP}]$ is provided. For detection of intracellular myc and HA epitopes, (permeabilized) transfected cells were permeabilized with saponin. $B$,

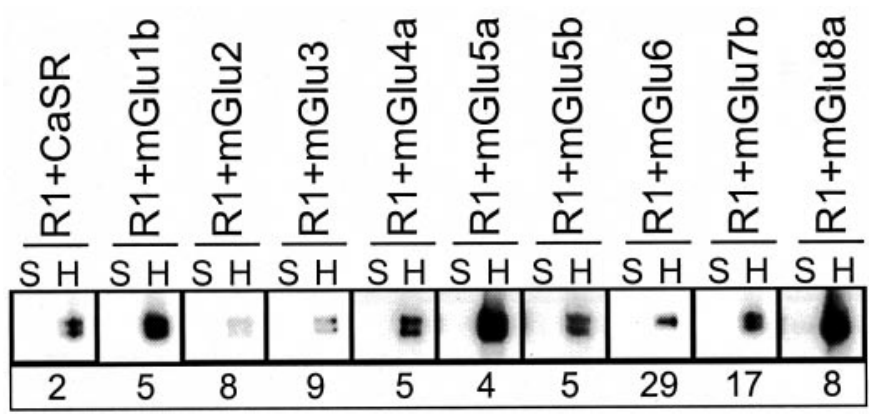

Figure 7. $\mathrm{Ca}^{2+}$-sensing $(\mathrm{CaSR})$ and $\mathrm{mGlu}$ receptors do not traffic WT $\mathrm{GABA}_{\mathrm{B}(1)}$ to the cell surface. Coexpressed proteins were always from identical species (rat or human). Surface photoaffinity-labeling experiments are as outlined in Figure $1 E$.

$\mathrm{GABA}_{\mathrm{B}(1)}$ (Sullivan et al., 2000). In that study, coexpression with mGlu4 led to the surface expression of $\mathrm{GABA}_{\mathrm{B}(1)}$ as determined by immunoblot analysis and flow cytometry. However, $\mathrm{mGlu}_{4}+\mathrm{GABA}_{\mathrm{B}(1)}$ heteromers were not formed, and no functional coupling of the monomer was observed.

We systematically analyzed in photoaffinity labeling experiments whether $\mathrm{Ca}^{2+}$-sensing and mGlu receptors mask the ERR/R signal in $\mathrm{GABA}_{\mathrm{B}(1)}$ and facilitate surface expression (Fig. 7). None of the receptors that were analyzed, including mGlu4, were able to convincingly deliver $\mathrm{GABA}_{\mathrm{B}(1)}$ to the cell surface. Consistent with this finding, none of the expressed proteins yielded functional $\mathrm{GABA}_{\mathrm{B}}$ receptors in combination with $\mathrm{GABA}_{\mathrm{B}(1)}$ and $\mathrm{GABA}_{\mathrm{B}(2)}$ (data not shown). It is of note that $\mathrm{mGlu} 5$ and the $\mathrm{Ca}^{2+}$-sensing receptors are as ineffective as the other $\mathrm{mGlu}$ receptors in trafficking $\mathrm{GABA}_{\mathrm{B}(1)}$, although they are well known to homodimerize (Romano et al., 1996; Ward et al., 1998; Bai et al., 1999; Ray et al., 1999). These data demonstrate that the shielding of the ERR/R signal contained in the cytoplasmic domain of $\mathrm{GABA}_{\mathrm{B}(1)}$ has structural requirements provided by the $\mathrm{GABA}_{\mathrm{B}(2)}$ backbone but not by the related $\mathrm{mGlu}$ or $\mathrm{Ca}^{2+}$-sensing receptor proteins.

\section{DISCUSSION}

To date, the physiological significance of GPCR dimerization remains largely unknown. $\mathrm{GABA}_{\mathrm{B}}$ receptors are currently the only example of where function depends on dimerization. GPCRs other than $\mathrm{GABA}_{\mathrm{B}}$, such as the serotonin (Xie et al., 1999), opioid (Jordan and Devi, 1999), dopamine $\mathrm{D}_{1}$ /adenosine $\mathrm{A}_{1}$ receptors (Ginés et al., 2000) and angiotensin II $\mathrm{AT}_{1} /$ bradykinin B2 (AbdAlla et al., 2000) have recently been shown to assemble from distinct subunits. Heteromerization can change pharmacological properties and potentiate signal transduction. This raises the possibility that heteromerization is a relevant and more common principle among GPCRs. Conceptually, this largely increases the

Surface expression in transfected primary cerebellar granule cells. Neurons transfected with myc-tagged WT GABA ${ }_{\mathrm{B}(1)}(R 1)$ alone do not show cell surface immunoreactivity. Strong c-myc surface staining is detected with cells cotransfected with WT GABA ${ }_{\mathrm{B}(1)}$ and $\mathrm{GABA}_{\mathrm{B}(2)}(R 1+R 2)$ and with mutant R1[ASARHPP]. For surface labeling, transfected cerebellar neurons were incubated with anti-c-myc antibody in culture medium for $1 \mathrm{hr}$, washed, and fixed with paraformaldehyde. Neurons were incubated for 1.5 hr with anti-mouse IgG Texas Red conjugate (1:1000), washed extensively, mounted on coverslips, and viewed with a $63 \times$ magnification objective. For labeling of permeabilized cells, paraformaldehyde-fixed neurons were permeabilized with $0.05 \%$ Triton X-100 before incubation with primary and secondary antibodies. Three independent experiments were performed. 
already vast repertoire of GPCRs and may significantly change our view of how these receptors operate. Understanding the mechanisms that govern assembly of functional heteromeric GPCRs is therefore a fundamental problem and may reveal dimerization partners that otherwise are difficult to discover.

For any protein that oligomerizes in the ER, the proper tertiary and quartenary structures must be achieved before the release. Sorting mechanisms are in place to discriminate between the unassembled subunits and completed oligomers. These mechanisms include, for example, the exposure and masking of short discrete ERR/R motifs. The best-characterized signals are the luminal KDEL sequences of soluble and type II transmembrane proteins (Munro and Pelham, 1987) and the cytoplasmic KK sequences of type I membrane proteins (Teasdale and Jackson, 1996). Other signals include RR (Schutze et al., 1994) or RXR (Zerangue et al., 1999) in the cytoplasmic domain of the retained protein.

It was shown that $\mathrm{GABA}_{\mathrm{B}(2)}$ can target to the cell surface by itself (Marshall et al., 1999). In contrast, $\mathrm{GABA}_{\mathrm{B}(1)}$ is retained in the ER in the absence of coexpressed $\mathrm{GABA}_{\mathrm{B}(2)}$, and heterodimerization results in a profound enhancement of surface expression (Couve et al., 1998; Marshall et al., 1999). The mechanism of plasma membrane targeting was not understood. We now show that a four amino acid motif in $\mathrm{GABA}_{\mathrm{B}(1)}$, RSRR, tightly inhibits the surface expression of monomers. The RSRR motif combines two known ERR/R signals: RXR (Zerangue et al., 1999) and RR (Schutze et al., 1994). One would assume that proteins possessing this enhanced motif would be retained more efficiently in the ER than those featuring the minimal motif.

$\mathrm{GABA}_{\mathrm{B}(2)}$ was found in yeast two-hybrid screens using the $\mathrm{GABA}_{\mathrm{B}(1)} \mathrm{C}$ terminus as a bait, suggesting that the leucine zippers were responsible for heteromerization of the $\operatorname{GABA}_{\mathrm{B}(1,2)}$ complex (White et al., 1998; Kammerer et al., 1999; Kuner et al., 1999). We show that a $\mathrm{GABA}_{\mathrm{B}(2)}$ C-terminal fragment, CR2P820, is sufficient to reverse the ER retention imposed by the RSRR motif (Fig. 4D). The close proximity of the RSRR motif to the C-terminal LZ1 suggests that the coiled-coil interaction is responsible for masking the ERR/R signal. In support of such an involvement, shielding of the ERR/R signal is lost once serial deletions of the $\mathrm{C}$ terminus of $\mathrm{GABA}_{\mathrm{B}(2)}$ progress into the leucine zipper domain (Fig. $4 C$ ) or when the LZ2 is deleted in R2 $\Delta$ LZ2 (Fig. $5 B$ ). Surprisingly, however, mutation of the leucine zipper in R1[PPP] still allows the formation of functional surface receptors together with $\mathrm{WT} \mathrm{GABA}_{\mathrm{B}(2)}$ and $\mathrm{R} 2[\mathrm{PPP}]($ Fig. $5 D, E)$. These latter results suggest that some shielding of the ERR/R signal still occurs when leucine zipper interactions are partly or completely destabilized. It does not imply, however, that in WT receptors the coiled-coil interaction is not involved in masking the ERR/R signal. Our conclusion from these seemingly conflicting results is that the leucine zipper interaction is involved in, but not absolutely necessary for, masking the ERR/R signal. Accordingly, functional interactions between $\mathrm{GABA}_{\mathrm{B}(1)}$ and $\mathrm{GABA}_{\mathrm{B}(2)}$ can still be obtained when leucine zipper interactions are weakened or prevented by mutation or deletion. From a therapeutic point of view, it appears that drugs that disrupt the coiled-coil interaction will not necessarily reduce the number of $\mathrm{GABA}_{\mathrm{B}}$ receptors expressed at the cell surface. Possibly the coiled-coil domains also serve functions other than $\mathrm{GABA}_{\mathrm{B}}$ surface trafficking and support interaction with additional proteins, such as recently shown for ATF-4 (Nehring et al., 2000).

Human $\mathrm{GABA}_{\mathrm{B}(1)}$ polymorphisms were described, but none of them involve the LZ1 domain or the RSRR motif (Sander et al., 1999). Known $\mathrm{GABA}_{\mathrm{B}(1)}$ splice variants conserve the $\mathrm{ERR} / \mathrm{R}$ signal and the LZ1 domain (Isomoto et al., 1998) (GeneBank accession number AJ012187). Moreover, two C-terminal splice variants of $\mathrm{GABA}_{\mathrm{B}(2)}$ (our unpublished data) do not alter the LZ2 domain. This emphasizes the importance of the coiled-coil domains for receptor maturation. We did not observe any trafficking of $\mathrm{GABA}_{\mathrm{B}(1)}$ to the surface when coexpressed with several family 3 GPCRs. However, it has been shown recently that ionotropic and metabotropic receptors are able to undergo a physical association (Liu et al., 2000). Proteins with unrelated structure therefore may traffic $\mathrm{GABA}_{\mathrm{B}(1)}$ to the cell surface. Although $\mathrm{GABA}_{\mathrm{B}(1)}$ monomers do not efficiently couple through $\mathrm{G} \alpha$ and $\mathrm{G} \beta \gamma$, it is possible that once at the cell surface $\mathrm{GABA}_{\mathrm{B}(1)}$ signals through G-protein independent-pathways, as shown for the mGlu receptors (Heuss et al., 1999). The interdependence between heteromerization, exit of $\mathrm{GABA}_{\mathrm{B}(1)}$ from the ER, and functional activity makes it difficult to separate the role of individual receptor domains. However, no obvious functional properties of heterologous $\mathrm{GABA}_{\mathrm{B}}$ receptors are lost when both $\mathrm{C}$ termini are deleted. It follows that the primary determinants for heteromeric receptor assembly and function do reside in the $\mathrm{N}$-terminal domain and TMD.

The ER trafficking signal identified here was first characterized in $\mathrm{K}_{\mathrm{ATP}}$ channels (Zerangue et al., 1999). This signal was proposed to serve as a quality control mechanism that ensures only the surface expression of properly assembled octameric channels. Because for WT subunits only $\mathrm{GABA}_{\mathrm{B}(1,2)}$ complexes are shown to be capable of robust signal transduction, a similar mechanisms may exist that prevents monomeric $\mathrm{GABA}_{\mathrm{B}(1)}$ from expressing on the cell surface. Mutations leading to truncation of the $\mathrm{C}$ terminus of SUR1 are one cause of a severe, recessive form of persistent hyperinsulinemic hypoglycemia of infancy, most likely because aberrant $\mathrm{K}_{\mathrm{ATP}}$ channels are formed (Zerangue et al., 1999). Because $\mathrm{GABA}_{\mathrm{B}(1)}$ monomers are functionally inert when expressed on the plasma membrane, they would not have obvious harmful effects. An important aspect of GPCR regulation is the control of the number of receptors expressed on the cell surface. The ERR/R signal identified here is poised to play a dynamic role in controlling the level of surface expression of heterodimeric receptors. Slow trafficking rates may create a large intracellular pool of $\mathrm{GABA}_{\mathrm{B}(1)}$ protein that is ready to go to the cell surface in the event that $\mathrm{GABA}_{\mathrm{B}(2)}$ is provided. For the $\mathrm{GABA}_{\mathrm{B}}$ receptors, ERR/R may therefore represent a means to rapidly regulate surface expression levels, as proposed similarly for Homer1b and mGlu5 (Roche et al., 1999).

After submission of this manuscript a similar study reporting the identification of the RSRR motif in $\mathrm{GABA}_{\mathrm{B}(1)}$ was published (Margeta-Mitrovic et al., 2000). The authors of that study reached conclusions that are mostly similar to ours. However, our data do not support the conclusion that "interaction of $\mathrm{GABA}_{\mathrm{B}(1)}$ and $\mathrm{GABA}_{\mathrm{B}(2)}$ through the $\mathrm{C}$-terminal coiled-coil $\alpha$ helices seems to be required not only for the shielding of the retention/retrieval signal RSRR in $\mathrm{GABA}_{\mathrm{B}(1)}$ but also for the functional activity of the fully assembled complex." Margeta-Mitrovic et al. (2000) base their statement on an experiment with point mutations in the coiled-coil and RSRR regions of $\mathrm{GABA}_{\mathrm{B}(1)}$. Although they observe surface expression of that $\mathrm{GABA}_{\mathrm{B}(1)}$ mutant, they do not see function on coexpression with $\mathrm{GABA}_{\mathrm{B}(2)}$. In contrast, we observe in all of our experiments with either deleted (Figs. $1 C, D$, $2 C, E, 3 B, D, E, 4 C, D)$ or mutated (Fig. $5 B, C, D, E$ ) coiled-coil domains, functional heteromeric receptors whenever the two subunits are coexpressed at the cell surface. This shows convincingly that the N-terminal domain and TMD of the two subunits 
are sufficient to assemble a functional heteromeric complex provided $\mathrm{GABA}_{\mathrm{B}(1)}$ exits the ER.

\section{Note}

The Nomenclature Committee of the International Union of Pharmacology recommendation for nomenclature of $\mathrm{GABA}_{\mathrm{B}}$ re-

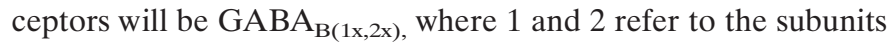
and $\mathrm{x}$ refers to the splice variants.

\section{REFERENCES}

AbdAlla S, Lother H, Quitterer U (2000) $\mathrm{AT}_{1}$-receptor heterodimers show enhanced G-protein activation and altered receptor sequestration. Nature 407:94-98.

Ango F, Albani-Torregrossa S, Joly C, Robbe D, Michel J-M, Pin J-P, Bockaert J, Fagni L (1999) A simple method to transfer plasmid DNA into neuronal primary cultures: functional expression of the mGlu5 receptor in cerebellar granule cells. Neuropharmacology 38:793-803.

Bai M, Trivedi S, Kifor O, Quinn SJ, Brown EM (1999) Intermolecular interactions between dimeric calcium-sensing receptor monomers are important for its normal function. Proc Natl Acad Sci USA 96:2834-2839.

Benke D, Honer M, Michel C, Bettler B, Möhler H (1999) $\gamma$-Aminobutyric acid type B receptor splice variant proteins GBR1a and GBR1b are both associated with GBR2 in situ and display differential regional and subcellular distribution. J Biol Chem 274:27323-27330.

Bettler B, Kaupmann K, Bowery N (1998) GABA B $_{\text {B }}$ receptors: drugs meet clones. Curr Opin Neurobiol 8:345-350.

Chang XB, Cui L, Hou YX, Jensen TJ, Aleksandrov AA, Mengos A, Riordan JR (1999) Removal of multiple arginine-framed trafficking signals overcomes misprocessing of $\Delta \mathrm{F} 508$ CFTR present in most patients with cystic fibrosis. Mol Cell 4:137-142

Couve A, Fillipov AK, Connolly CN, Bettler B, Brown DA, Moss SJ (1998) Intracellular retention of recombinant $\mathrm{GABA}_{\mathrm{B}}$ receptors. J Biol Chem 273:26361-26367.

Filippov AK, Couve A, Pangalos MN, Walsh FS, Brown DA, Moss SJ (2000) Heteromeric assembly of $\mathrm{GABA}_{\mathrm{B}} \mathrm{R} 1$ and $\mathrm{GABA}_{\mathrm{B}} \mathrm{R} 2$ receptor subunits inhibits $\mathrm{Ca}^{2+}$ current in symphathetic neurons. J Neurosci 20:2867-2874

Flor PJ, Gomeza J, Tones MA, Kuhn R, Pin J-P, Knöpfel T (1996) The $\mathrm{C}$-terminal domain of the mGluR1 metabotropic glutamate receptor affects sensitivity to agonists. J Neurochem 67:58-63.

Francesconi A, Duvoisin RM (1998) Role of the second and third intracellular loops of metabotropic glutamate receptors in mediating dual signal transduction activation. J Biol Chem 273:5615-5624.

Franek M, Pagano A, Kaupmann K, Bettler B, Pin J-P, Blahos J (1999) The heteromeric GABA-B receptor recognizes G-protein alpha subunit C-termini. Neuropharmacology 38:1657-1666.

Galvez T, Parmentier M-L, Joly C, Malitschek B, Kaupmann K, Kuhn R, Bittiger H, Froestl W, Bettler B, Pin J-P (1999) Mutagenesis and modeling of the $\mathrm{GABA}_{\mathrm{B}}$ receptor extracellular domain support a Venus Flytrap mechanism for ligand binding. J Biol Chem 274:13362-13369.

Ginés S, Hillion J, Torvinen M, Le Crom S, Casadó V, Canela EI, Rondin S, Lew JY, Watson S, Zoli M, Agnati LF, Vernier P, Lluis C, Ferré S, Fuxe K, Franco R (2000) Dopamine $D_{1}$ and adenosine $A_{1}$ receptors form functionally interacting heteromeric complexes. Proc Natl Acad Sci USA 97:8606-8611.

Heuss C, Scanziani M, Gähwiler BH, Gerber U (1999) G-proteinindependent signaling mediated by metabotropic glutamate receptors. Nat Neurosci 2:1070-1077.

Isomoto S, Kaibara M, Sakurai-Yamashita Y, Nagayama Y, Uezono Y, Yano K, Taniyama K (1998) Cloning and tissue distribution of novel splice variants of the rat $\mathrm{GABA}_{\mathrm{B}}$ receptor. Biochem Biophys Res Commun 253:10-15.

Jordan BA, Devi LA (1999) G-protein-coupled receptor heterodimerization modulates receptor function. Nature 399:697-700.

Kammerer RA, Frank S, Schulthess T, Landwehr R, Lustig A, Engel J (1999) Heterodimerization of a functional $\mathrm{GABA}_{\mathrm{B}}$ receptor is mediated by parallel coiled-coil $\alpha$-helices. Biochemistry 38:13263-13269.

Kaupmann K, Huggel K, Heid J, Flor PJ, Bischoff S, Mickel SJ, McMaster G, Angst C, Bittiger H, Froestl W, Bettler B (1997) Expression cloning of $\mathrm{GABA}_{\mathrm{B}}$ receptors uncovers similarity to metabotropic glutamate receptors. Nature 386:239-246.

Kaupmann K, Malitschek B, Schuler V, Heid J, Froestl W, Beck P, Mosbacher J, Bischoff S, Kulik A, Shigemoto R, Karschin A, Bettler B (1998a) GABA $_{B}$-receptor subtypes assemble into functional heteromeric complexes. Nature 396:683-687.

Kaupmann K, Schuler V, Mosbacher J, Bischoff S, Bittiger H, Heid J, Froestl W, Leonhard S, Pfaff T, Karschin A, Bettler B (1998b) Human gamma-aminobutyric acid type $\mathrm{B}$ receptors are differentially expressed and regulate inwardly rectifying $\mathrm{K}^{+}$channels. Proc Natl Acad Sci USA 95:14991-14996.

Kim U, Sanchez-Vives MV, McCormick DA (1997) Functional dynamics of GABAergic inhibition in the thalamus. Science 278:130-134.

Kuner R, Kohr G, Grunewald S, Eisenhardt G, Bach A, Kornau HC (1999) Role of heteromer formation in $\mathrm{GABA}_{\mathrm{B}}$ receptor function. Science 283:74-77.

Liu F, Wan Q, Pristupa ZB, Yu XM, Wang YT, Niznik HB (2000) Direct protein-protein coupling enables cross-talk between dopamine D5 and gamma-aminobutyric acid A receptors. Nature 403:274-280.

Lupas A (1996) Coiled coils: new structures and new functions. Trends Biochem Sci 21:375-382.

Malashkevich VN, Kammerer RA, Efimov VP, Schulthess T, Engel J (1996) The crystal structure of a five-stranded coiled coil in COMP: a prototype ion channel? Science 274:761-765.

Malitschek B, Rüegg D, Heid J, Kaupmann K, Bittiger H, Fröstl W, Bettler B, Kuhn R (1998) Developmental changes of agonist affinity at $\mathrm{GABA}_{\mathrm{B}} \mathrm{R} 1$ receptor variants in rat brain. Mol Cell Neurosci 12:56-64.

Malitschek B, Schweizer C, Keir M, Heid J, Froestl W, Mosbacher J, Kuhn R, Henley J, Joly C, Pin J-P, Kaupmann K, Bettler B (1999) The $\mathrm{N}$-terminal domain of $\mathrm{GABA}_{\mathrm{B}}$ receptors is sufficient to specify agonist and antagonist binding. Mol Pharmacol 56:448-454.

Margeta-Mitrovic M, Jan YN, Jan LY (2000) A trafficking checkpoint controls $\mathrm{GABA}_{\mathrm{B}}$ receptor heterodimerization. Neuron 27:97-106.

Marshall FH, Jones KA, Kaupmann K, Bettler B (1999) GABA receptors: the first 7TM heterodimers. Trends Pharmacol Sci 20:396-399.

Munro S, Pelham HRB (1987) A carboxyl-terminal signal prevents secretion of luminal ER proteins. Cell 48:899-907.

Nehring RB, Horikawa HP, El Far O, Kneussel M, Brandstätter JH, Stamm S, Wischmeyer E, Betz H, Karschin A (2000) The metabotropic $\mathrm{GABA}_{\mathrm{B}}$ receptor interacts with the activating transcription factor 4 (ATF-4). J Biol Chem 275:35185-35191.

Pin JP, Joly C, Heinemann SF, Bockaert J (1994) Domains involved in the specificity of $\mathrm{G}$ protein activation in phospholipase $\mathrm{C}$-coupled metabotropic glutamate receptors. EMBO J 13:342-348.

Ray K, Hauschild BC, Steinbach PJ, Goldsmith PK, Hauache O, Spiegel AM (1999) Identification of the cysteine residues in the aminoterminal extracellular domain of the human $\mathrm{Ca}^{2+}$ receptor critical for dimerization. J Biol Chem 274:27642-27650.

Roche KW, Tu JC, Petralia RS, Xiao B, Wenthold RJ, Worley PF (1999) Homer $1 \mathrm{~b}$ regulates the trafficking of group I metabotropic glutamate receptors. J Biol Chem 274:25953-25957.

Romano C, Yang WL, O'Malley KL (1996) Metabotropic glutamate receptor 5 is a disulfide-linked dimer. J Biol Chem 271:28612-28616.

Salahpour A, Angers S, Bouvier M (2000) Functional significance of oligomerization of G-protein-coupled receptors. Trends Endocrinol Metab 11:163-168.

Sander T, Peters C, Kämmer G, Samochowiec J, Zirra M, Mischke D, Ziegler A, Kaupmann K, Bettler B, Epplen JT, Riess O (1999) Association analysis of exonic variants of the gene encoding the $\mathrm{GABA}_{\mathrm{B}}$ receptor and idiopathic generalized epilepsy. Am J Med Genet 88:305-310.

Schutze MP, Peterson PA, Jackson MR (1994) An N-terminal doublearginine motif maintains type II membrane proteins in the endoplasmic reticulum. EMBO J 13:1696-1705.

Sullivan R, Chateauneuf A, Coulombe N, Kolakowski Jr LF, Johnson MP, Hebert TE, Ethier N, Belley M, Metters K, Abramovitz M, O'Neill GP, Ng GYK (2000) Co-expression of full-length $\gamma$-aminobutyric acid ${ }_{\mathrm{B}}\left(\mathrm{GABA}_{\mathrm{B}}\right)$ receptors with truncated receptors and metabotropic glutamate receptor 4 supports the $\mathrm{GABA}_{\mathrm{B}}$ heterodimer as the functional receptor. J Pharmacol Exp Ther 293:460-467.

Teasdale RD, Jackson MR (1996) Signal-mediated sorting of membrane proteins between the endoplasmic reticulum and the Golgi apparatus. Annu Rev Cell Dev Biol 12:27-54.

Van-Vliet BJ, Sebben M, Dumuis A, Gabrion J, Bockaert J, Pin J-P (1989) Endogenous amino acid release from cultured cerebellar neuronal cells: effect of tetanus toxin on glutamate release. J Neurochem 52:1229-1239.

Ward DT, Brown EM, Harris HW (1998) Disulfide bonds in the extracellular calcium-polyvalent cation-sensing receptor correlate with dimer formation and its response to divalent cations in vitro. $\mathrm{J}$ Biol Chem 273:14476-14483.

White JH, Wise A, Main MJ, Green A, Fraser NJ, Disney GH, Barnes AA, Emson P, Foord SM, Marshall FH (1998) Heterodimerization is required for the formation of a functional $\mathrm{GABA}_{\mathrm{B}}$ receptor. Nature 396:679-682

Xie Z, Lee SP, O'Dowd BF, George SR (1999) Serotonin 5-HT 1в $_{\text {B }}$ and 5 - $\mathrm{HT}_{1 \mathrm{D}}$ receptors form homodimers when expressed alone and heterodimers when co-expressed. FEBS Lett 456:63-67.

Zerangue N, Schwappach B, Jan YN, Jan LY (1999) A new ER trafficking signal regulates the subunit stoichiometry of plasma membrane $\mathrm{K}_{\text {ATP }}$ channels. Neuron 22:537-548. 